\title{
Carbon-Carbon Bonds Functioning as Electron Shuttles: The Generation of Electron-Rich Manganese(II)-Schiff Base Complexes and Their Redox Chemistry
}

\author{
Emma Gallo ${ }^{\dagger}$ Euro Solari, ${ }^{\dagger}$ Nazzareno Re, ${ }^{\ddagger}$ Carlo Floriani, $*, \dagger$ \\ Angiola Chiesi-Villa, ${ }^{\S}$ and Corrado Rizzoli ${ }^{\S}$

\begin{abstract}
Contribution from the Institut de Chimie Minérale et Analytique, BCH, Université de Lausanne, CH-1015 Lausanne, Switzerland, Dipartimento di Chimica, Università di Perugia, I-06100 Perugia, Italy, and Dipartimento di Chimica, Università di Parma, I-43100 Parma, Italy
\end{abstract}

Received November 27, $1996^{\otimes}$

\begin{abstract}
The reduction of [Mn(II)-salophen] derivatives [salophen $=N, N^{\prime}$-ethylenebis(salicylideneaminato) dianion] led to the formation of $\mathrm{C}-\mathrm{C}$ bridged dimers. Such $\mathrm{C}-\mathrm{C}$ bonds function as two electron shuttles in electron-transfer reactions. The reduction of $[\mathrm{Mn}(\text { salophen })(\mathrm{THF})]_{2}(\mathbf{1})$ and $\left[\mathrm{Mn}\left(3,5-\mathrm{Bu}_{4}^{\mathrm{t}} \text { salophen }\right)(\mathrm{THF})\right]_{2}(\mathbf{3})$ with 2 equiv of sodium metal led to the corresponding single $\mathrm{C}-\mathrm{C}$ bond bridged dimers, $\left[\mathrm{Mn}_{2}\left(\operatorname{salophen}_{2}\right) \mathrm{Na}_{2}(\mathrm{DME})_{4}\right](\mathbf{5})\left[\operatorname{salophen}_{2}=\right.$ $\mathrm{C}-\mathrm{C}$ bonded salophen dimer] and $\left[\mathrm{Mn}_{2}\left(3,5-\mathrm{Bu}_{4}^{\mathrm{t}} \mathrm{Salophen}_{2}\right) \mathrm{Na}_{2}(\mathrm{DME})_{6}\right](\mathbf{7})$, respectively. Complexes 5 and 7 undergo a further two electron reduction to $\left[\mathrm{Mn}_{2}\left({ }^{*}\right.\right.$ salophen $\left.\left._{2}{ }^{*}\right) \mathrm{Na}_{4}(\mathrm{DME})_{6}\right](6)\left[{ }^{*}\right.$ salophen $_{2} *=\mathrm{C}-\mathrm{C}$ doubly bonded salophen dimer] and $\left[\mathrm{Mn}_{2}\left(* 3,5-\mathrm{Bu}_{4}^{\mathrm{t}} \mathrm{Salophen}_{2} * \mathrm{Na}_{4}(\mathrm{DME})_{4}\right](\mathbf{8})\right.$, respectively, both containing a double $\mathrm{C}-\mathrm{C}$ bridge. The obtention of $\left.\left[\mathrm{Mn}_{2}\left\{\text { salophen }(\mathrm{Me}) \mathrm{CH}_{2}\right)\right\}_{2} \mathrm{Na}_{4}(\mathrm{DME})_{4}\right]$ (9) from [Mn(salophen-Me $\left.\mathrm{Me}_{2}(\mathrm{THF})\right]_{2}$ (2) strongly supports the existence of free radical precursors in the formation of $\mathrm{C}-\mathrm{C}$ bonds. Complex $\mathbf{6}$ has been used as a source of four electrons in a number of reactions, thus reduction of $\mathrm{Ag}^{+}, \mathrm{PhCH}_{2} \mathrm{Cl}, p$-benzoquinone, and $\left[\mathrm{Co}^{\mathrm{II}}(\mathrm{MeOsalen})\right]$ occurs with the regeneration of the starting material 1 . The $\mathrm{C}-\mathrm{C}$ bond cleavage is the source of electrons, without being involved in any reaction as a reactive site. With stronger oxidizing agents not only complexes $\mathbf{6}$ and $\mathbf{8}$ transfer the electrons stored at the $\mathrm{C}-\mathrm{C}$ bonds but also the metal undergoes a change in the oxidation state. The reaction of $\mathbf{6}$ with dioxygen produces a novel form of di- $\mu$-oxo-Mn(IV) dimers, where the salophen ligand displays a bridging bonding mode in $\left[\mathrm{Mn}_{2}(\mu \text {-salophen })_{2}(\mu-\mathrm{O})_{2}\right](\mathbf{1 5})$ and $\left[\mathrm{Mn}_{2}\left(\mu-3,5-\mathrm{Bu}^{\mathrm{t}} \text { salophen }\right)_{2}(\mu-\mathrm{O})_{2}\right](\mathbf{1 6})$.
\end{abstract}

\section{Introduction}

The chemistry presented in this paper concerns the design of molecules which contain at the same time an active site like a transition metal and an additional functionality which is devoted to the storage and delivery of electrons. The latter one should be different from the metal itself. To couple a metal and an independent electron reservoir in the same molecule may open attractive perspectives in the molecular design of molecules devoted to energy storage (molecular batteries) or for a functioning mode in charge storage different from that in Photosystem II. ${ }^{1}$

Let us consider the most common mechanisms by which we can store and release electrons from molecules. The most obvious involves changing the oxidation state of the metal, thus a number of single electrons are made available at different potentials. Another, though from an organic perspective, involves the use of polyaromatic systems able to accept electrons in the $\pi^{*}$ orbitals, though this is limited in its storage capacity. ${ }^{2}$ A third possibility concerns the formation and cleavage of chemical bonds. This latter mechanism would make available electron in pairs and relatively large in number. The reductive

\footnotetext{
* To whom correspondence should be addressed.

$\dagger$ University of Lausanne.

* University of Perugia.

$\S$ University of Parma.

${ }^{\otimes}$ Abstract published in Advance ACS Abstracts, May 1, 1997.

(1) (a) Photosynthesis; Briggs, W. R., Ed.; ARL: New York, 1989. (b) The Photosynthetic Reaction Center. Deisenhofer, J., Norris, J. R., Eds.; Academic: New York, 1993 Vol. I and II. (c) Manganese Redox Enzymes; Pecoraro, V. L., Ed.; VCH: New York, 1992. (d) Wieghardt, K. Angew. Chem., Int. Ed. Engl. 1989, 28, 1153.

(2) (a) Foster, R. Organic Charge Transfer Complexes; Academic: London, 1969. (b) Miller, L. L.; Mann, K. R. Acc. Chem. Res. 1996, 29,
} 417. or the oxidative coupling and their reverse, which are wellknown classes of reaction in organometallic chemistry, can be used for the formation and cleavage of bonds. A significant example comes from the natural redox relationship between cysteine and cystine. ${ }^{3}$

We report here how we can store electrons in the formation of the most common $\mathrm{C}-\mathrm{C}$ bonds, via the reversible reductive coupling of imino groups belonging to a tetradentate Schiff base ligand, that is salophen $[N, N$-ethylenebis(salicylideneaminato) dianion] bonded to manganese(II). This observation has been made, though not exhaustively explored, by us in the past in some reductions of $\mathrm{Ni}-, \mathrm{V}-$, and $\mathrm{Co}-$ salophen complexes. ${ }^{4}$ These $\mathrm{C}-\mathrm{C}$ bonds are oxidatively cleaved in a number of reactions, without being directly involved as reactive sites in the same reaction. To couple $\mathrm{Mn}$ and an intramolecular electron reservoir may be of relevant significance in designing artificial Photosystems II. ${ }^{1}$

We give here an account on the electron-rich manganese(II) derived from the stepwise reduction of the model compounds: $\left.[\mathrm{Mn} \text { (salophen)(thf })_{2}\right]$ and $\left[\mathrm{Mn}\left(3,5-\mathrm{Bu}_{4}^{\mathrm{t}} \text { salophen }\right)(\text { thf })\right]_{2}$ and their behavior on the reoxidation using mainly dioxygen and quinones. A few of the present results have been briefly communicated. ${ }^{5}$

(3) Fluharty, A. L. In The chemistry of the thiol group; Patai, Ed.; Wiley: London, 1974; Chapter 13, p 601.

(4) Gambarotta, S.; Floriani, C.; Chiesi-Villa, A.; Guastini, C. J. Chem. Soc., Chem. Commun. 1982, 756. (b) Gambarotta, S.; Urso, F.; Floriani, C.; Chiesi-Villa, A.; Guastini, C. Inorg. Chem. 1983, 22, 3966. (c) Gambarotta, S.; Mazzanti, M.; Floriani, C.; Zehnder, M. J. Chem. Soc., Chem. Commun. 1984, 1116. (d) De Angelis, S.; Solari, E.; Gallo, E.; Floriani, C.; Chiesi-Villa, A.; Rizzoli, C. Inorg. Chem. 1996, 35, 5995 and references therein.

(5) Gallo, E.; Solari, E.; De Angelis, S.; Floriani, C.; Re, N.; ChiesiVilla, A.; Rizzoli, C. J. Am. Chem. Soc. 1993, 115, 9850. 


\section{Scheme 1}

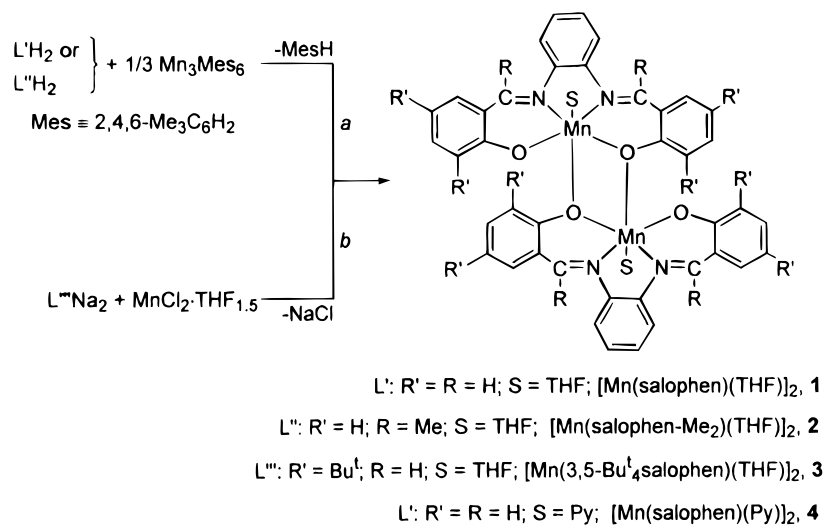

\section{Results and Discussion}

1. Starting Compounds. The synthesis of compounds $\mathbf{1}$ and $\mathbf{2}$ has been carried out using an organometallic method (in Scheme 1, $a$ ) in order to avoid (i) the presence of alkali and ammonium salts in the final product; (it is well-known that metal-Schiff base complexes bind a variety of organic and inorganic cations); ${ }^{6}$ (ii) protic conditions; and (iii) separation of poorly soluble final products from salts. This method is now particularly convenient, due to the scaled up synthesis of $\mathrm{Mn}_{3^{-}}$ Mes $_{6}$, $\left[\right.$ Mes $\left.\equiv 2,4,6-\mathrm{Me}_{3} \mathrm{C}_{6} \mathrm{H}_{2}\right] .{ }^{7}$

In the case of $\mathbf{3}$, its high solubility allowed the use of the conventional metathetical reaction with $\mathrm{MnCl}_{2}$ for the synthesis (Scheme 1,b). Complexes $\mathbf{1 - 3}$ have been isolated as dimers in their solvated form with THF, which can be easily replaced by other solvents like pyridine in 4 . The structure of such dimeric forms is exemplified by the report on the X-ray analysis of 4 , while the magnetic properties will be discussed along with those of the other dimers reported through the paper. Selected bond distances and angles are quoted in Tables 1-4 for complexes 4-6, and 9, respectively. In Table 5 a comparison of relevant conformational parameters is given for all complexes. We anticipate that complex $\mathbf{4}$ consists of discrete dimeric units (Figure 1). Manganese exhibits a pseudo-octahedral coordination with the $\mathrm{N}_{2} \mathrm{O}_{2}$ set of atoms from the salophen ligand in the equatorial plane and the pyridine molecule in an axial position, while the sixth coordination site is occupied by the oxygen of a second monomeric unit at a rather long distance [Mn1A-

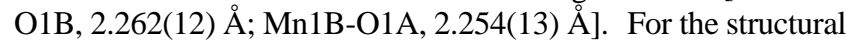
$\mathrm{Mn}-\mathrm{O}$, and $\mathrm{Mn}-\mathrm{N}$ parameters we refer to Table 1 , since they are in the range expected for $\mathrm{Mn}(\mathrm{II})-$ Schiff base complexes. ${ }^{8,9}$ The $\mathrm{N}_{2} \mathrm{O}_{2}$ core is not planar, showing remarkable tetrahedral

(6) (a) Guerriero, P.; Tamburini, S.; Vigato, P. A. Coord. Chem. Rev. 1995, 139, 17. (b) Floriani, C.; Calderazzo, F.; Randaccio, L. J. Chem. Soc., Chem. Commun. 1973, 384. (c) Gambarotta, S.; Corazza, F.; Floriani, C.; Zehnder, M. J. Chem. Soc., Chem. Commun. 1984, 1305. (d) Horwitz, C. P.; Ciringh, Y. Inorg. Chim. Acta 1994, 225, 191. (e) Bresciani-Pahor, N.; Calligaris, M.; Delise, P.; Nardin, G.; Randaccio, L.; Zotti, E.; Fachinetti, G.; Floriani, C. J. Chem. Soc., Dalton Trans. 1976, 2310. (f) Horwitz, C. P.; Warden, J. T.; Weintraub, S. T. Inorg. Chim. Acta 1996, 246, 311320. (g) Giacomelli, A.; Floriani, C.; Perego, G. J. Chem. Soc., Chem. Commun. 1982, 650. (h) Solari, E.; Floriani, C.; Cunningham, D.; Higgins, T.; McArdle, P. J. Chem. Soc., Dalton Trans. 1991, 3139. (i) Gibney, B R.; Wang, H.; Kampf, J. W.; Pecoraro, V. L. Inorg. Chem. 1996, 35, 6184.

(7) Solari, E.; Musso, F.; Gallo, E.; Floriani, C.; Re, N.; Chiesi-Villa, A.; Rizzoli, C. Organometallics 1995, 14, 2265.

(8) Srinavan, K.; Michaud, J. K. J. Am. Chem. Soc. 1986, 108, 2309. (9) (a) Luaces, L.; Bermejo, M: R.; Garcia-Vazquez, J. A.; Romero, S.; Sousa, A.; Watkinson, M.; Mugnier, Y.; McAuliffe, C. A.; Pritchard, R. G.; Helliwell, M. Polyhedron 1996, 15, 1375. (b) Higuchi, C.; Sakiyama, H.; Okawa, H.; Isobe, R.; Fenton, D. E. J. Chem. Soc., Dalton Trans. 1994, 1097. (c) Kessissoglou, D. P.; Butler, W. M.; Pecoraro, V. L. Inorg. Chem. 1987, 26, 495. (d) Mabad, B.; Cassoux, P.; Tuchagues, J.-P.; Hendrickson, D. N. Inorg. Chem. 1986, 25, 1420. (e) Gallo, E.; Solari, E.; Floriani, C.; Chiesi-Villa, A.; Rizzoli, C. Organometallics 1995, 14, 2156.
Table 1. Selected Bond Distances $(\AA)$ and Angles (deg) for Complex 4

\begin{tabular}{|c|c|c|c|c|}
\hline & \multicolumn{2}{|c|}{ molecule A } & \multicolumn{2}{|c|}{ molecule B } \\
\hline $\mathrm{Mn} 1-\mathrm{O} 1$ & \multicolumn{2}{|c|}{$2.087(10)$} & \multicolumn{2}{|c|}{$2.097(10)$} \\
\hline $\mathrm{Mn} 1-\mathrm{O} 2$ & \multicolumn{2}{|c|}{$2.062(13)$} & \multicolumn{2}{|c|}{$2.015(13)$} \\
\hline $\mathrm{Mn} 1-\mathrm{N} 1$ & \multicolumn{2}{|c|}{$2.217(17)$} & \multicolumn{2}{|c|}{$2.238(16)$} \\
\hline $\mathrm{Mn} 1-\mathrm{N} 2$ & \multicolumn{2}{|c|}{$2.212(18)$} & \multicolumn{2}{|c|}{$2.200(17)$} \\
\hline $\mathrm{Mn} 1-\mathrm{N} 3$ & \multicolumn{2}{|c|}{$2.382(15)$} & \multicolumn{2}{|c|}{$2.387(15)$} \\
\hline $\mathrm{O} 1-\mathrm{C} 1$ & \multicolumn{2}{|c|}{$1.31(2)$} & \multicolumn{2}{|c|}{$1.36(2)$} \\
\hline $\mathrm{O} 2-\mathrm{C} 20$ & \multicolumn{2}{|c|}{$1.30(3)$} & \multicolumn{2}{|c|}{$1.31(3)$} \\
\hline $\mathrm{N} 1-\mathrm{C} 7$ & \multicolumn{2}{|c|}{$1.31(3)$} & \multicolumn{2}{|c|}{$1.27(3)$} \\
\hline $\mathrm{N} 1-\mathrm{C} 8$ & \multicolumn{2}{|c|}{ 1.41(3) } & \multicolumn{2}{|c|}{$1.41(3)$} \\
\hline $\mathrm{N} 2-\mathrm{C} 13$ & \multicolumn{2}{|c|}{$1.46(3)$} & \multicolumn{2}{|c|}{$1.43(3)$} \\
\hline $\mathrm{N} 2-\mathrm{C} 14$ & \multicolumn{2}{|c|}{$1.26(3)$} & \multicolumn{2}{|c|}{$1.33(3)$} \\
\hline $\mathrm{N} 3-\mathrm{C} 21$ & \multicolumn{2}{|c|}{$1.31(3)$} & \multicolumn{2}{|c|}{$1.36(3)$} \\
\hline $\mathrm{N} 3-\mathrm{C} 25$ & \multicolumn{2}{|c|}{$1.36(3)$} & \multicolumn{2}{|c|}{$1.34(3)$} \\
\hline $\mathrm{N} 1-\mathrm{Mn} 1-\mathrm{N} 2$ & \multicolumn{2}{|l|}{$73.2(7)$} & & $75.1(6)$ \\
\hline $\mathrm{O} 2-\mathrm{Mn} 1-\mathrm{N} 2$ & \multicolumn{2}{|l|}{$86.3(6)$} & & $85.4(6)$ \\
\hline $\mathrm{O} 2-\mathrm{Mn} 1-\mathrm{N} 1$ & \multicolumn{2}{|l|}{$159.2(6)$} & & $160.0(6)$ \\
\hline $\mathrm{O} 1-\mathrm{Mn} 1-\mathrm{N} 2$ & \multicolumn{2}{|l|}{$158.2(7)$} & & $159.0(6)$ \\
\hline $\mathrm{O} 1-\mathrm{Mn} 1-\mathrm{N} 1$ & \multicolumn{2}{|l|}{$85.9(5)$} & & $84.9(5)$ \\
\hline $\mathrm{O} 1-\mathrm{Mn} 1-\mathrm{O} 2$ & \multicolumn{2}{|l|}{$114.8(5)$} & & $115.0(5)$ \\
\hline $\mathrm{Mn} 1-\mathrm{O} 1-\mathrm{C} 1$ & $124.4(11)$ & & & $125.6(11)$ \\
\hline $\mathrm{Mn} 1-\mathrm{O} 2-\mathrm{C} 20$ & $130.8(13)$ & & & $132.2(13)$ \\
\hline $\mathrm{Mn} 1 \mathrm{~A}-\mathrm{O} 1 \mathrm{~B}$ & $2.262(12)$ & Mn1F & & $2.254(13)$ \\
\hline N3A-Mn1A-O1B & $169.3(6)$ & N3B- & D1A & $169.3(5)$ \\
\hline $\mathrm{Mn} 1 \mathrm{~A}-\mathrm{O} 1 \mathrm{~A}-\mathrm{Mn} 1 \mathrm{~B}$ & $102.2(4)$ & Mn1 & Mn1B & $101.6(4)$ \\
\hline $\mathrm{C} 1 \mathrm{~A}-\mathrm{O} 1 \mathrm{~A}-\mathrm{Mn} 1 \mathrm{~B}$ & $114.5(11)$ & $\mathrm{C} 1 \mathrm{~B}-$ & $\mathrm{n} 1 \mathrm{~A}$ & $115.2(11)$ \\
\hline
\end{tabular}

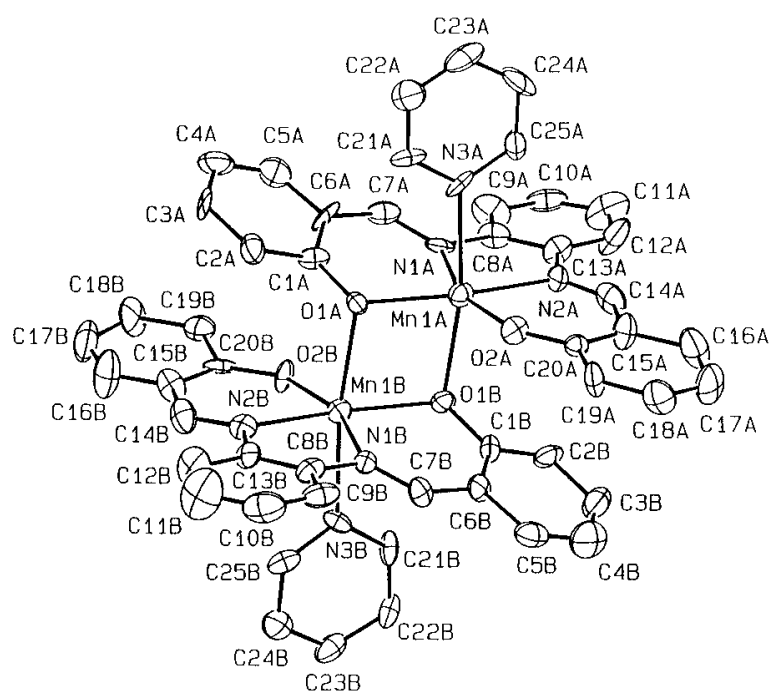

Figure 1. ORTEP view of complex 4.

distortions (Table 5). Each [Mn(salophen)] moiety assumes a twisted "umbrella" conformation, the dihedral angles between peripheral phenolic rings being $19.0(7)$ and $21.8(8)^{\circ}$ for moiety $\mathrm{A}$ and $\mathrm{B}$, respectively.

The temperature dependence of the magnetic moments of the starting compounds $\mathbf{1 - 4}$ are typical of weakly coupled $\mathrm{Mn}$ (II) dimers. The data of $\mathbf{3}$, taken as representative of the four compounds (1-4), were fitted with the simple theoretical equation ${ }^{10}$ obtained by the Heisenberg spin hamiltonian $H_{\mathrm{ex}}=$ $-2 J \hat{S}_{1}-\hat{S}_{2}$, with $S_{1}=S_{2}=5 / 2$. To obtain a good fitting, we included a correction for a small quantity of monomeric Mn(II) impurities, $x$, which were assumed to obey Curie law, obtaining $g=1.97, J=-4.7 \mathrm{~cm}^{-1}$, and $x=1.8 \%{ }^{11}$

2. Reduced Forms of [Mn(salophen)] Derivatives. Complex $\mathbf{1}$ undergoes a stepwise reduction to $\mathbf{5}$ and $\mathbf{6}$ in the reaction with sodium metal in THF. The sequence is pictorially shown

(10) O’Connor, C. J. Progr. Inorg. Chem. 1982, 29, 203.

(11) A detailed report on the magnetic properties of all the dimeric compounds cited in this paper is in the Supporting Information. 
Table 2. Selected Bond Distances $(\AA)$ and Angles (deg) for Complex 5

\begin{tabular}{|c|c|c|c|c|c|}
\hline & $\mathrm{Mn} 1-\mathrm{O} 1$ & $2.036(7)$ & $\mathrm{Mn} 2-\mathrm{O} 2$ & $1.995(7)$ & \\
\hline & $\mathrm{Mn} 1-\mathrm{O} 4$ & $2.027(6)$ & $\mathrm{Mn} 2-\mathrm{O} 3$ & $2.011(7)$ & \\
\hline & $\mathrm{Mn} 1-\mathrm{N} 1$ & $2.208(10)$ & $\mathrm{Mn} 2-\mathrm{N} 3$ & $2.213(8)$ & \\
\hline & $\mathrm{Mn} 1-\mathrm{N} 2$ & $2.135(7)$ & $\mathrm{Mn} 2-\mathrm{N} 2$ & $2.182(6)$ & \\
\hline & $\mathrm{Mn} 1-\mathrm{N} 4$ & $2.184(9)$ & $\mathrm{Mn} 2-\mathrm{N} 4$ & $2.143(8)$ & \\
\hline & $\mathrm{Na} 1-\mathrm{O} 1$ & $2.353(6)$ & $\mathrm{Na} 2-\mathrm{O} 2$ & $2.401(8)$ & \\
\hline & $\mathrm{Na} 1-\mathrm{O} 4$ & $2.525(6)$ & $\mathrm{Na} 2-\mathrm{O} 3$ & $2.398(7)$ & \\
\hline & $\mathrm{Na} 1-\mathrm{O} 5$ & $2.458(9)$ & $\mathrm{Na} 2-\mathrm{O} 7$ & $2.403(11)$ & \\
\hline & $\mathrm{Na} 1-\mathrm{O} 6$ & $2.304(14)$ & $\mathrm{Na} 2-\mathrm{O} 8$ & $2.438(11)$ & \\
\hline & & & $\mathrm{Na} 2-\mathrm{O} 9$ & $2.611(13)$ & \\
\hline & & & $\mathrm{Na} 2-\mathrm{O} 10$ & $2.405(12)$ & \\
\hline & $\mathrm{O} 1-\mathrm{C} 1$ & $1.336(13)$ & $\mathrm{O} 3-\mathrm{C} 21$ & $1.329(12)$ & \\
\hline & $\mathrm{O} 2-\mathrm{C} 20$ & $1.351(12)$ & $\mathrm{O} 4-\mathrm{C} 40$ & $1.355(13)$ & \\
\hline & $\mathrm{N} 1-\mathrm{C} 7$ & $1.281(14)$ & $\mathrm{N} 3-\mathrm{C} 27$ & $1.306(13)$ & \\
\hline & $\mathrm{N} 1-\mathrm{C} 8$ & $1.437(12)$ & $\mathrm{N} 3-\mathrm{C} 28$ & $1.394(14)$ & \\
\hline & $\mathrm{N} 2-\mathrm{C} 13$ & $1.378(14)$ & $\mathrm{N} 4-\mathrm{C} 33$ & $1.367(14)$ & \\
\hline & $\mathrm{N} 2-\mathrm{C} 14$ & $1.443(14)$ & $\mathrm{N} 4-\mathrm{C} 34$ & $1.508(11)$ & \\
\hline & $\mathrm{C} 14-\mathrm{C} 34$ & $1.602(15)$ & & & \\
\hline & $\mathrm{C} 14-\mathrm{C} 15$ & $1.543(13)$ & C34-C35 & $1.504(11)$ & \\
\hline $\mathrm{N} 2-\mathrm{Mn} 1-\mathrm{N} 4$ & $69.8(3)$ & $\mathrm{N} 2-\mathrm{Mn} 2-\mathrm{N} 4$ & $69.6(3)$ & $\mathrm{O} 3-\mathrm{Na} 2-\mathrm{O} 10$ & $96.9(3)$ \\
\hline $\mathrm{N} 1-\mathrm{Mn} 1-\mathrm{N} 4$ & $131.5(3)$ & $\mathrm{N} 2-\mathrm{Mn} 2-\mathrm{N} 3$ & $129.5(3)$ & $\mathrm{O} 3-\mathrm{Na} 2-\mathrm{O} 9$ & $97.8(3)$ \\
\hline $\mathrm{N} 1-\mathrm{Mn} 1-\mathrm{N} 2$ & $74.8(3)$ & $\mathrm{N} 3-\mathrm{Mn} 2-\mathrm{N} 4$ & $73.0(3)$ & $\mathrm{O} 3-\mathrm{Na} 2-\mathrm{O} 8$ & $163.4(4)$ \\
\hline $\mathrm{O} 4-\mathrm{Mn} 1-\mathrm{N} 4$ & $94.8(3)$ & $\mathrm{O} 2-\mathrm{Mn} 2-\mathrm{N} 2$ & $93.0(3)$ & $\mathrm{O} 3-\mathrm{Na} 2-\mathrm{O} 7$ & $97.0(3)$ \\
\hline $\mathrm{O} 4-\mathrm{Mn} 1-\mathrm{N} 2$ & $106.6(3)$ & $\mathrm{O} 2-\mathrm{Mn} 2-\mathrm{N} 4$ & $109.0(3)$ & $\mathrm{O} 2-\mathrm{Na} 2-\mathrm{O} 10$ & $100.0(3)$ \\
\hline $\mathrm{O} 4-\mathrm{Mn} 1-\mathrm{N} 1$ & $126.9(3)$ & $\mathrm{O} 2-\mathrm{Mn} 2-\mathrm{N} 3$ & $131.1(3)$ & $\mathrm{O} 2-\mathrm{Na} 2-\mathrm{O} 9$ & $164.6(4)$ \\
\hline $\mathrm{O} 1-\mathrm{Mn} 1-\mathrm{N} 4$ & $118.8(3)$ & $\mathrm{O} 3-\mathrm{Mn} 2-\mathrm{N} 2$ & $120.3(3)$ & $\mathrm{O} 2-\mathrm{Na} 2-\mathrm{O} 8$ & $104.4(3)$ \\
\hline $\mathrm{O} 1-\mathrm{Mn} 1-\mathrm{N} 2$ & $156.2(3)$ & $\mathrm{O} 3-\mathrm{Mn} 2-\mathrm{N} 4$ & $155.4(3)$ & $\mathrm{O} 2-\mathrm{Na} 2-\mathrm{O} 7$ & $105.0(4)$ \\
\hline $\mathrm{O} 1-\mathrm{Mn} 1-\mathrm{N} 1$ & $84.5(3)$ & $\mathrm{O} 3-\mathrm{Mn} 2-\mathrm{N} 3$ & $84.8(3)$ & $\mathrm{O} 2-\mathrm{Na} 2-\mathrm{O} 3$ & $74.8(3)$ \\
\hline $\mathrm{O} 1-\mathrm{Mn} 1-\mathrm{O} 4$ & $95.1(2)$ & $\mathrm{O} 2-\mathrm{Mn} 2-\mathrm{O} 3$ & $93.4(3)$ & & \\
\hline $\mathrm{O} 5-\mathrm{Na} 1-\mathrm{O} 6$ & 69.1(4) & $\mathrm{O} 9-\mathrm{Na} 2-\mathrm{O} 10$ & $67.0(4)$ & & \\
\hline $\mathrm{O} 4-\mathrm{Na} 1-\mathrm{O} 6$ & $100.3(3)$ & $\mathrm{O} 8-\mathrm{Na} 2-\mathrm{O} 10$ & $99.5(4)$ & & \\
\hline $\mathrm{O} 4-\mathrm{Na} 1-\mathrm{O} 5$ & 169.1(3) & $\mathrm{O} 8-\mathrm{Na} 2-\mathrm{O} 9$ & $86.5(4)$ & & \\
\hline $\mathrm{O} 1-\mathrm{Na} 1-\mathrm{O} 6$ & $107.2(4)$ & $\mathrm{O} 7-\mathrm{Na} 2-\mathrm{O} 10$ & $153.8(4)$ & & \\
\hline $\mathrm{O} 1-\mathrm{Na} 1-\mathrm{O} 5$ & $104.6(3)$ & $\mathrm{O} 7-\mathrm{Na} 2-\mathrm{O} 9$ & 89.1(4) & & \\
\hline $\mathrm{O} 1-\mathrm{Na} 1-\mathrm{O} 4$ & $75.8(2)$ & $\mathrm{O} 7-\mathrm{Na} 2-\mathrm{O} 8$ & $67.0(4)$ & & \\
\hline $\mathrm{Mn} 1-\mathrm{N} 2-\mathrm{Mn} 2$ & $81.0(3)$ & $\mathrm{Mn} 1-\mathrm{N} 4-\mathrm{Mn} 2$ & $80.8(3)$ & $\mathrm{N} 2-\mathrm{C} 14-\mathrm{C} 34$ & $108.2(7)$ \\
\hline $\mathrm{Mn} 2-\mathrm{N} 2-\mathrm{C} 14$ & $101.4(6)$ & $\mathrm{Mn} 2-\mathrm{N} 4-\mathrm{C} 34$ & $112.7(5)$ & $\mathrm{N} 2-\mathrm{C} 14-\mathrm{C} 15$ & $117.0(8)$ \\
\hline $\mathrm{Mn} 2-\mathrm{N} 2-\mathrm{C} 13$ & $119.4(6)$ & $\mathrm{Mn} 2-\mathrm{N} 4-\mathrm{C} 33$ & $115.6(5)$ & $\mathrm{C} 15-\mathrm{C} 14-\mathrm{C} 34$ & $113.0(8)$ \\
\hline $\mathrm{Mn} 1-\mathrm{N} 2-\mathrm{C} 14$ & $113.0(5)$ & $\mathrm{Mn} 1-\mathrm{N} 4-\mathrm{C} 34$ & $102.3(6)$ & $\mathrm{N} 4-\mathrm{C} 34-\mathrm{C} 14$ & $103.2(7)$ \\
\hline $\mathrm{Mn} 1-\mathrm{N} 2-\mathrm{C} 13$ & $113.6(6)$ & $\mathrm{Mn} 1-\mathrm{N} 4-\mathrm{C} 33$ & $121.4(5)$ & $\mathrm{N} 4-\mathrm{C} 34-\mathrm{C} 35$ & $117.3(7)$ \\
\hline $\mathrm{C} 13-\mathrm{N} 2-\mathrm{C} 14$ & $121.1(8)$ & $\mathrm{C} 33-\mathrm{N} 4-\mathrm{C} 34$ & $118.0(8)$ & C14-C34-C35 & $113.5(8)$ \\
\hline
\end{tabular}

\section{Scheme 2}

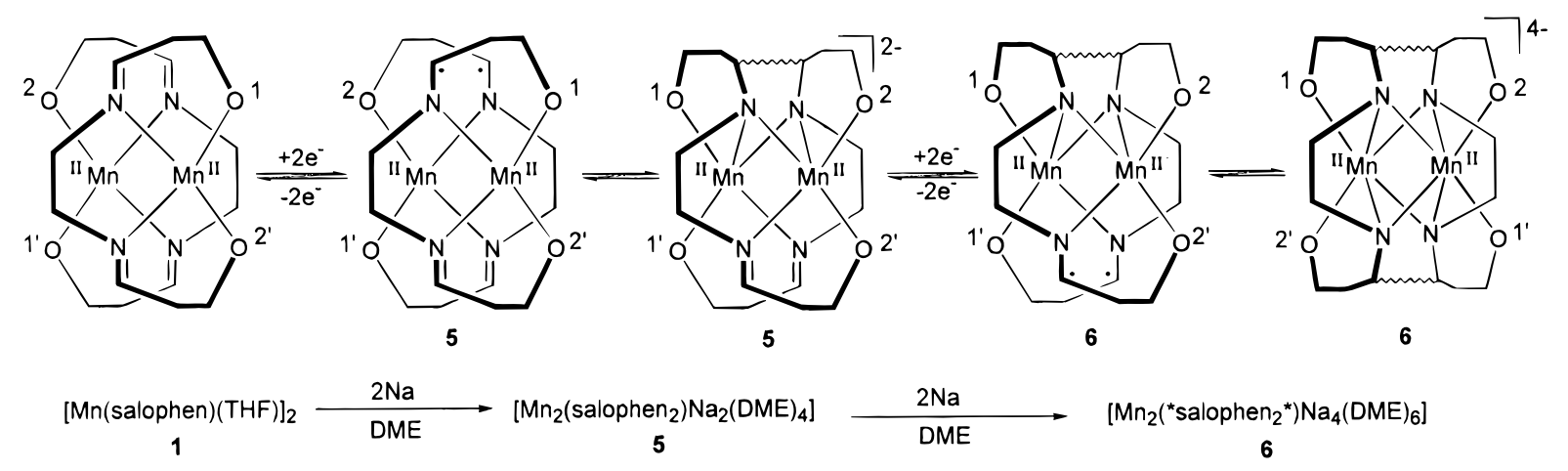

in Scheme 2, which is based on the structural information on $\mathbf{1 , 5}$, and 6; the upper part showing the structural consequences on the two salophen skeletons upon reduction, the lower part showing the corresponding chemical equations.

The starting material $\mathbf{1}$ is drawn as two overlapping nonbonded monomeric units, since we omitted for clarity the bridging oxygen interaction (see the structure of 4). The introduction of two electrons into the dimer causes the reductive coupling of two imino groups across the two monomers with the consequent formation of a $\mathrm{C}-\mathrm{C}$ bond (complex 5).,5 The structural analysis on $\mathbf{5}$ (vide infra) shows, however, that the $\mathrm{C}-\mathrm{C}$ bond formation is accompanied by a change in the bonding mode of the salophen skeleton. Such a change in the bonding mode can be visualized by rotating the two oxygen arms involved in the $\mathrm{C}-\mathrm{C}$ bond formation in the opposite direction, as it can be easily followed using the oxygen labeling used in Scheme 2. At the same time the two related nitrogens display a bridging bond across the two Mn. The further introduction of two electrons leading from $\mathbf{5}$ to $\mathbf{6}$ has the same effect on the other pair of imino groups. The oxygen labeling in Scheme 2 shows that the four electron reduction causes not only the $\mathrm{C}-\mathrm{C}$ bond formation but the formal exchange of the two salophen skeletons between the two Mn.

The anionic species depicted in Scheme 2 has been isolated as tight ion-pairs with sodium cations and with the stoichiometry shown at the bottom of the scheme. The synthesis of $\mathbf{6}$ has been carried out with a large excess of sodium metal, while the formation of $\mathbf{5}$ with controlled amounts of sodium is not 


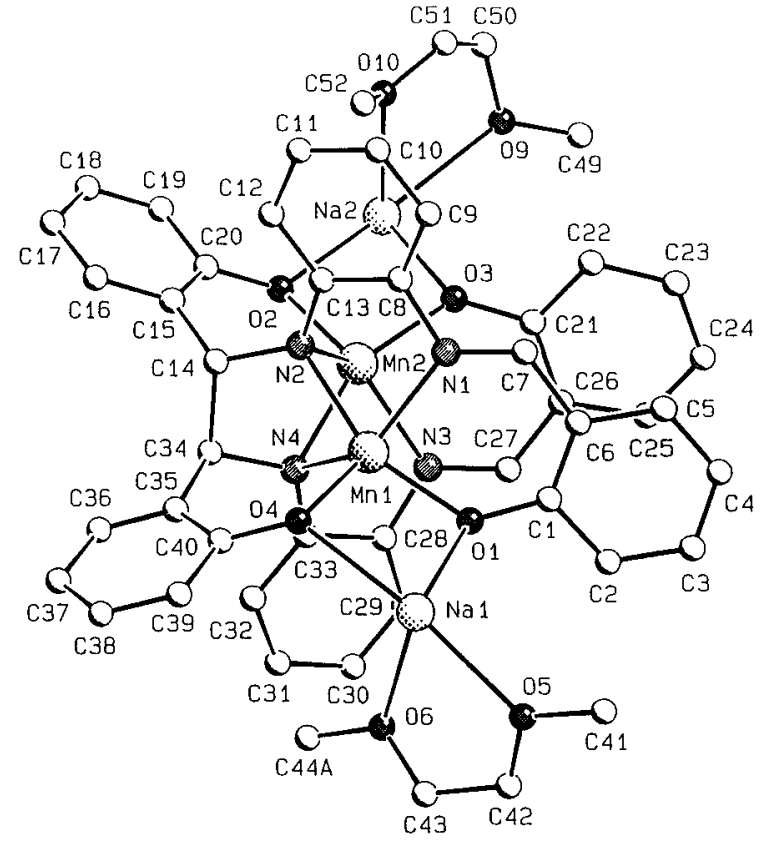

Figure 2. SCHAKAL view of complex 5. The O7, O8, C45-C48 DME molecule bonded to $\mathrm{Na} 2$ and the $\mathrm{B}$ position of $\mathrm{C} 44$ are omitted for clarity.

particularly wise, because it should be separated from a mixture containing 6. Independent high yield synthesis of $\mathbf{5}$ has been discovered (vide infra). Pure 5 undergoes reduction to 6 . The occurrence of a mixture of $\mathbf{5}$ and $\mathbf{6}$ even using limited amounts of $\mathrm{Na}$ suggests that the reduction of $\mathbf{5}$ to $\mathbf{6}$ is significantly faster than $\mathbf{1}$ to $\mathbf{5}$. Both $\mathbf{5}$ and $\mathbf{6}$ have been fully characterized (see Experimental Section), including magnetic studies (see magnetic section) and an X-ray analysis. The structure of 5, shown in Figure 2, displays the main features given in Scheme 2.

The $\mathrm{C}-\mathrm{C}$ bond $[\mathrm{C} 14-\mathrm{C} 34,1.602(15) \AA]$ bridging the two salophen units is particularly long, as is the case for very crowded structures. As a consequence of the $\mathrm{sp}^{3}$ character of these imino carbons the phenolic rings $\mathrm{O} 2, \mathrm{C} 15 \cdots \mathrm{C} 20$ and $\mathrm{O} 4$,$\mathrm{C} 35 \cdots \mathrm{C} 40$ are nearly perpendicular to the remaining part of the salophen, the dihedral angles with $\mathrm{N} 1, \mathrm{~N} 2, \mathrm{O} 1, \mathrm{C} 1 \cdots \mathrm{C} 13$ and $\mathrm{N} 3, \mathrm{~N} 4, \mathrm{O} 3, \mathrm{C} 35 \cdots \mathrm{C} 40$ best planes being $105.5(2)^{\circ}$ and 102.9$(2)^{\circ}$, respectively. In such a conformation the planarity of the $\mathrm{N}_{2} \mathrm{O}_{2}$ salophen core is lost, and the ligand behaves as a tridentate $\mathrm{N}-\mathrm{N}-\mathrm{O}$ ligand toward one $\mathrm{Mn}$ and either $\mathrm{O} 2$ or $\mathrm{O} 4$ binds the adjacent manganese. Therefore the original salophen has been converted into the dinucleating hexa-anionic salophen ligand. $_{2}$ The two $\mathrm{Mn}$ achieve a trigonal bipyramidal coordination geometry thanks to the bridging bonding mode of $\mathrm{N} 2$ and $\mathrm{N} 4$.

The folding of salophen allowed the pair of atoms $\mathrm{O} 2, \mathrm{O} 3$ and $\mathrm{O} 1, \mathrm{O} 4$ to position at bite distances of 2.915(10) and 3.000(8) $\AA$, respectively, thus functioning as bidentate ligands for $\mathrm{Na} 2$ and Na3 cations. Their coordination spheres are completed with DME molecules (see Figure S6). The structural Mn-N and $\mathrm{Mn}-\mathrm{O}$ parameters do not show any particularity except for the rather short $\mathrm{Mn} 1-\mathrm{N} 2$ and Mn2-N4 [Mn- $\mathrm{N}_{\mathrm{av}}, 2.138(5)$ Å] involving the anionic nitrogens (Table 2). The major structural changes on moving from 5 to 6 (Figure 3) have been depicted in Scheme 2.

The 2-fold coupled salophen moieties joined by two $\mathrm{C}-\mathrm{C}$ bonds $\left[\mathrm{C} 7-\mathrm{C} 14^{\prime}, 1.631(6) \AA\right]$ form the centrosymmetric dinucleating octaanionic * salophen $_{2} *$ ligand, which has been drawn without the metal centers in Figure 4.

The two centrosymmetric manganese atoms are bonded to the opposite sides of the centrosymmetric N4 planar core at distances ranging from 2.154(3) to 2.281(3) A. The coordina-
Table 3. Selected Bond Distances $(\AA)$ and Angles (deg) for Complex $6^{a}$

\begin{tabular}{|c|c|c|c|}
\hline $\mathrm{Mn} 1-\mathrm{O} 1$ & $2.171(4)$ & $\mathrm{Na} 1-\mathrm{O} 5$ & $2.481(6)$ \\
\hline $\mathrm{Mn} 1-\mathrm{O} 2$ & $2.121(3)$ & $\mathrm{Na} 1-\mathrm{O} 6$ & $2.416(5)$ \\
\hline $\mathrm{Mn} 1-\mathrm{N} 1$ & $2.258(3)$ & $\mathrm{Na} 2-\mathrm{O} 1$ & $2.459(4)$ \\
\hline $\mathrm{Mn} 1-\mathrm{N} 1^{\prime}$ & $2.174(4)$ & $\mathrm{Na} 2-\mathrm{O} 2$ & $2.460(4)$ \\
\hline $\mathrm{Mn} 1-\mathrm{N} 2$ & $2.281(3)$ & $\mathrm{Na} 2-\mathrm{O} 7$ & $2.469(4)$ \\
\hline $\mathrm{Mn} 1-\mathrm{N} 2^{\prime}$ & $2.154(3)$ & $\mathrm{Na} 2-\mathrm{O} 8$ & $2.400(4)$ \\
\hline $\mathrm{Na} 1-\mathrm{O} 1$ & $2.329(3)$ & $\mathrm{O} 1-\mathrm{C} 1$ & $1.330(5)$ \\
\hline $\mathrm{Na} 1-\mathrm{O} 2$ & $2.391(3)$ & $\mathrm{O} 2-\mathrm{C} 20$ & $1.330(5)$ \\
\hline $\mathrm{Na} 1-\mathrm{O} 3$ & $2.514(4)$ & $\mathrm{C} 7-\mathrm{C} 14^{\prime}$ & $1.631(6)$ \\
\hline $\mathrm{Na} 1-\mathrm{O} 4$ & $2.347(4)$ & & \\
\hline $\mathrm{N} 2-\mathrm{Mn} 1-\mathrm{N} 2^{\prime}$ & 106.1(1) & $\mathrm{O} 7-\mathrm{Na} 2-\mathrm{O} 8$ & $68.1(1)$ \\
\hline $\mathrm{N} 1^{\prime}-\mathrm{Mn} 1-\mathrm{N} 2^{\prime}$ & $70.6(1)$ & $\mathrm{O} 2-\mathrm{Na} 2-\mathrm{O} 8$ & 107.3(1) \\
\hline $\mathrm{N} 1^{\prime}-\mathrm{Mn} 1-\mathrm{N} 2$ & $68.5(1)$ & $\mathrm{O} 2-\mathrm{Na} 2-\mathrm{O} 7$ & $154.4(2)$ \\
\hline $\mathrm{N} 1-\mathrm{Mn} 1-\mathrm{N} 2^{\prime}$ & $69.3(1)$ & $\mathrm{O} 1-\mathrm{Na} 2-\mathrm{O} 8$ & $149.6(1)$ \\
\hline $\mathrm{N} 1-\mathrm{Mn} 1-\mathrm{N} 2$ & $66.9(1)$ & $\mathrm{O} 1-\mathrm{Na} 2-\mathrm{O} 7$ & 105.1(1) \\
\hline $\mathrm{N} 1-\mathrm{Mn} 1-\mathrm{N} 1^{\prime}$ & $106.0(1)$ & $\mathrm{O} 1-\mathrm{Na} 2-\mathrm{O} 2$ & 65.4(1) \\
\hline $\mathrm{O} 2-\mathrm{Mn} 1-\mathrm{N} 2^{\prime}$ & $165.3(1)$ & $\mathrm{Na} 1-\mathrm{O} 1-\mathrm{Na} 2$ & $94.3(1)$ \\
\hline $\mathrm{O} 2-\mathrm{Mn} 1-\mathrm{N} 2$ & 85.1(1) & $\mathrm{Mn} 1-\mathrm{O} 1-\mathrm{Na} 2$ & $87.3(1)$ \\
\hline $\mathrm{O} 2-\mathrm{Mn} 1-\mathrm{N} 1^{\prime}$ & 106.1(1) & $\mathrm{Mn} 1-\mathrm{O} 1-\mathrm{Na} 1$ & $89.7(1)$ \\
\hline $\mathrm{O} 2-\mathrm{Mn} 1-\mathrm{N} 1$ & $124.7(1)$ & $\mathrm{Na} 2-\mathrm{O} 1-\mathrm{C} 1$ & $107.8(2)$ \\
\hline $\mathrm{O} 1-\mathrm{Mn} 1-\mathrm{N} 2^{\prime}$ & $102.6(1)$ & $\mathrm{Na} 1-\mathrm{O} 1-\mathrm{C} 1$ & 136.3(3) \\
\hline $\mathrm{O} 1-\mathrm{Mn} 1-\mathrm{N} 2$ & 128.1(1) & $\mathrm{Mn} 1-\mathrm{O} 1-\mathrm{C} 1$ & $127.5(3)$ \\
\hline $\mathrm{O} 1-\mathrm{Mn} 1-\mathrm{N} 1^{\prime}$ & 163.3(1) & $\mathrm{Na} 1-\mathrm{O} 2-\mathrm{Na} 2$ & 92.7(1) \\
\hline $\mathrm{O} 1-\mathrm{Mn} 1-\mathrm{N} 1$ & 84.7(1) & $\mathrm{Mn} 1-\mathrm{O} 2-\mathrm{Na} 2$ & $88.4(1)$ \\
\hline $\mathrm{O} 1-\mathrm{Mn} 1-\mathrm{O} 2$ & $76.6(1)$ & $\mathrm{Mn} 1-\mathrm{O} 2-\mathrm{Na} 1$ & $89.3(1)$ \\
\hline $\mathrm{O} 5-\mathrm{Na} 1-\mathrm{O} 6$ & $66.8(2)$ & $\mathrm{Na} 2-\mathrm{O} 2-\mathrm{C} 20$ & 111.4(3) \\
\hline $\mathrm{O} 4-\mathrm{Na} 1-\mathrm{O} 6$ & $154.6(2)$ & $\mathrm{Na} 1-\mathrm{O} 2-\mathrm{C} 20$ & $135.2(3)$ \\
\hline $\mathrm{O} 4-\mathrm{Na} 1-\mathrm{O} 5$ & $88.1(2)$ & $\mathrm{Mn} 1-\mathrm{O} 2-\mathrm{C} 20$ & $127.0(3)$ \\
\hline $\mathrm{O} 3-\mathrm{Na} 1-\mathrm{O} 6$ & $112.1(2)$ & $\mathrm{Mn} 1-\mathrm{N} 1-\mathrm{C} 8$ & $102.0(2)$ \\
\hline $\mathrm{O} 3-\mathrm{Na} 1-\mathrm{O} 5$ & $85.7(2)$ & $\mathrm{Mn} 1-\mathrm{N} 1-\mathrm{C} 7$ & $105.5(2)$ \\
\hline $\mathrm{O} 3-\mathrm{Na} 1-\mathrm{O} 4$ & $67.5(1)$ & $\mathrm{C} 7-\mathrm{N} 1-\mathrm{C} 8$ & $128.3(3)$ \\
\hline $\mathrm{O} 2-\mathrm{Na} 1-\mathrm{O} 6$ & $104.0(1)$ & $\mathrm{Mn} 1-\mathrm{N} 1^{\prime}-\mathrm{C} 7^{\prime}$ & $116.2(3)$ \\
\hline $\mathrm{O} 2-\mathrm{Na} 1-\mathrm{O} 5$ & $117.0(2)$ & $\mathrm{Mn} 1-\mathrm{N} 2-\mathrm{C} 14$ & $104.6(2)$ \\
\hline $\mathrm{O} 2-\mathrm{Na} 1-\mathrm{O} 4$ & $83.5(1)$ & $\mathrm{Mn} 1-\mathrm{N} 2-\mathrm{C} 13$ & $101.8(2)$ \\
\hline $\mathrm{O} 2-\mathrm{Na} 1-\mathrm{O} 3$ & $142.9(1)$ & $\mathrm{C} 13-\mathrm{N} 2-\mathrm{C} 14$ & $127.5(3)$ \\
\hline $\mathrm{O} 1-\mathrm{Na} 1-\mathrm{O} 6$ & $107.0(2)$ & $\mathrm{Mn} 1-\mathrm{N} 2^{\prime}-\mathrm{C} 14^{\prime}$ & $116.9(2)$ \\
\hline $\mathrm{O} 1-\mathrm{Na} 1-\mathrm{O} 5$ & $172.2(2)$ & $\mathrm{N} 1-\mathrm{C} 7-\mathrm{C} 6$ & $118.5(3)$ \\
\hline $\mathrm{O} 1-\mathrm{Na} 1-\mathrm{O} 4$ & 98.3(1) & $\mathrm{C} 6-\mathrm{C} 7-\mathrm{C} 14^{\prime}$ & $109.2(3)$ \\
\hline $\mathrm{O} 1-\mathrm{Na} 1-\mathrm{O} 3$ & $92.5(1)$ & $\mathrm{N} 1-\mathrm{C} 7-\mathrm{C} 14^{\prime}$ & $107.0(3)$ \\
\hline $\mathrm{O} 1-\mathrm{Na} 1-\mathrm{O} 2$ & $68.5(1)$ & & \\
\hline
\end{tabular}

${ }^{a}$ Prime denotes a transformation of $1-x, y, 1-z$.

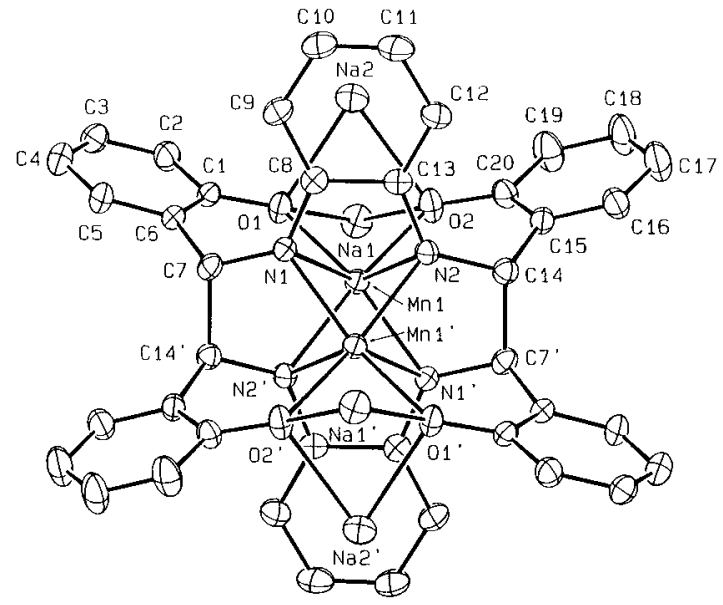

Figure 3. ORTEP view of complex 6 (30\% probability ellipsoids). DME molecules bonded to sodium are omitted for clarity. Prime denotes a transformation of $1-x,-y, 1-z$.

tion around each metal is completed by two cis arranged oxygens [O1, O2 around Mn1] (Figure 5).

Referring to Figure 5, it should be mentioned (i) that $\mathrm{Mn}$ does not occupy the center of the prism, the displacements from the three faces $\mathrm{O} 1, \mathrm{O} 2, \mathrm{~N} 1, \mathrm{~N} 2 ; \mathrm{O} 1, \mathrm{O} 2, \mathrm{~N}^{\prime}{ }^{\prime}, \mathrm{N} 2^{\prime}$; and $\mathrm{N} 1, \mathrm{~N} 2, \mathrm{~N}^{\prime}{ }^{\prime}$,$\mathrm{N} 2$ ' being 0.988(1), 0.287(1), and 1.330(1) A respectively; (ii)

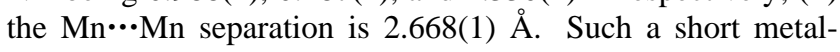




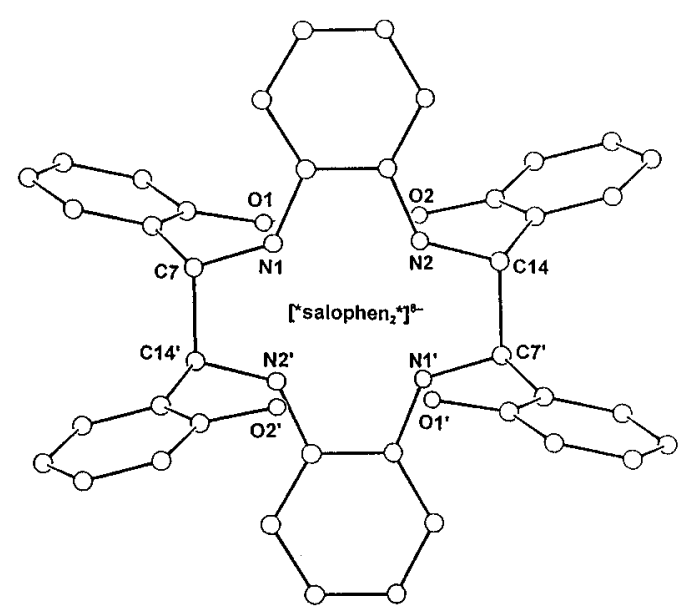

Figure 4. SCHAKAL view of the doubly $\mathrm{C}-\mathrm{C}$ bond bridged salophen, *salophen*, in complex 6.

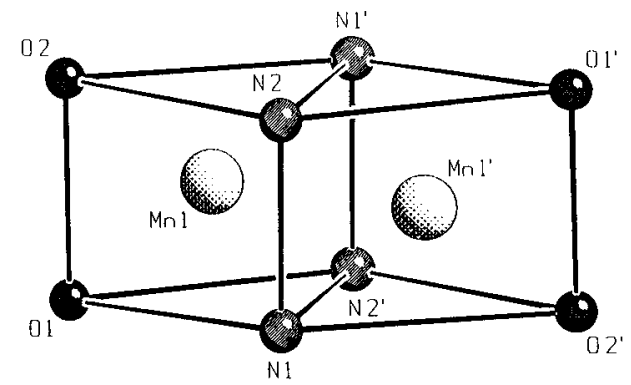

Figure 5. SCHAKAL drawing of coordination polyhedra around manganese cations in complex $\mathbf{6}$.

metal distance is particularly relevant in Mn dimers involved in redox processes. ${ }^{1 \mathrm{~d}, 12}$ The ${ }^{*}$ salophen $_{2}{ }^{*}$ ligand defines an approximately planar 12-membered ring (see Figure 4) [maximum deviation $0.123(3) \AA$ for N2] which is almost coplanar with the two $o$-phenylendiamine rings.

The $\mathrm{N}_{2} \mathrm{O}_{2}$ cores are almost perpendicular to the planar macroring system [dihedral angle $89.4(1)^{\circ}$ ]. The conformation of the ligand allowed the $\mathrm{O} 1$ and $\mathrm{O} 2$ to function twice as a bidentate ligand for $\mathrm{Na} 1$ and $\mathrm{Na} 2$, which complete their coordination spheres with two and one DME molecules (not shown in Figure 3 , see Figure $\mathrm{S} 7$ ), respectively. In the later case, the $\mathrm{O}_{4}$ set is almost planar with Na2 displaced by 0.599(2) $\AA$ from it toward the $\mathrm{C} 8 \cdots \mathrm{C} 13 \mathrm{ring}$, which is almost coplanar with the $\mathrm{O}_{4}$ core [dihedral angle $8.5(1)^{\circ}$ ]. The rather short range of the $\mathrm{Na} 2 \cdots \mathrm{C}$ distances (from $2.834(5)$ to $3.288(6) \AA$ ) suggests a Na2 $\cdots \eta^{6}$ (C8-C13) interaction, with a Na2 $\cdots$ ring centroid separation of $2.715(5) . .^{13}$

The search for an improved synthesis of $\mathbf{5}$ led us to discover a major property of the $\mathrm{C}-\mathrm{C}$ bound Schiff base ligands. Mixing equimolar amounts of $\mathbf{1}$ and $\mathbf{6}$ in DME at room temperature leads to $90 \%$ of $\mathbf{5}$ as red violet crystals (Scheme 3), through the same steps discussed in detail in Scheme 2.

The occurrence of such a reaction is significant in many respects: $(i)$ the $\mathrm{C}-\mathrm{C}$ bond formation and cleavage is reversible (see the reduction of 5 to 6 and reaction in Scheme 3); (ii) the $\mathrm{C}-\mathrm{C}$ bond functions as a shuttle of two electrons; and (iii) such an electron transfer can occur intermolecularly. As far as the latter point is concerned, we believe that the reaction between $\mathbf{1}$ and $\mathbf{6}$ is most probably assisted by the alkali cations which allow the two species to come in contact via coordination to the same sodium ions.

(12) (a) Manchanda, R.; Brudvig, G. W.; Crabtree, R. H. Coord. Chem. Rev. 1995, 144, 1. (b) Pecoraro, V. L.; Baldwin, M. S.; Gelasco, A. Chem. Rev. 1994, 94, 807.

(13) Weiss, E. Angew. Chem., Int. Ed. Engl. 1993, 32, 1501.
Scheme 3
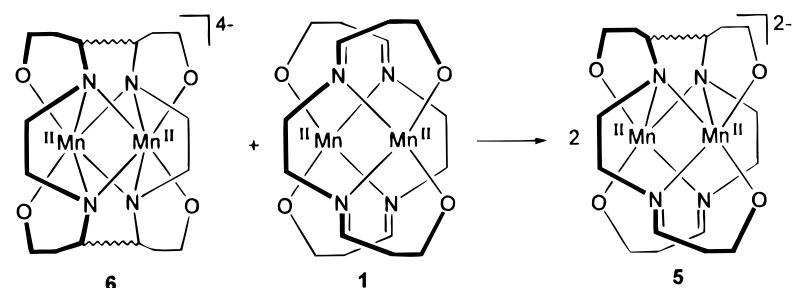

$\left[\mathrm{Mn}_{2}\left({ }^{*}\right.\right.$ salophen $\left.\left._{2}{ }^{*}\right) \mathrm{Na}_{4}(\mathrm{DME})_{6}\right]+[\mathrm{Mn}(\text { salophen })(\mathrm{THF})]_{2} \stackrel{\mathrm{DME}}{\longrightarrow}$

6

$2\left[\mathrm{Mn}_{2}\right.$ ( salophen $\left.\left._{2}\right) \mathrm{Na}_{2}(\mathrm{DME})_{4}\right]$

5

Scheme 4

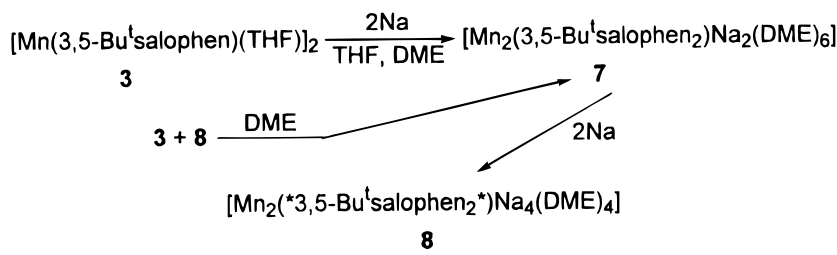

Scheme 5

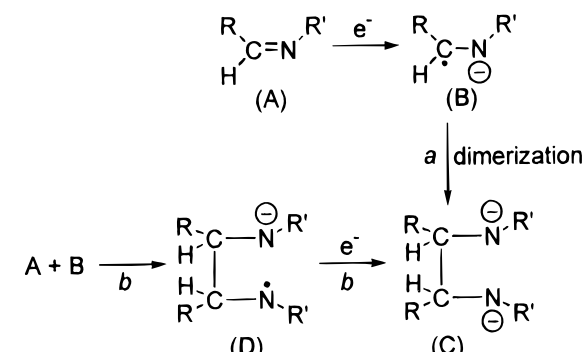

(D)

(C)

We should mention at this point that the parallel synthetic pathway and redox behavior have been observed for the $\mathrm{Bu}^{\mathrm{t}}$ substituted salophen-manganese complex $\mathbf{3}$, as reported in Scheme 4.

The $\mathrm{Bu}^{\mathrm{t}}$ substituents allowed us in many cases to better manage the solubility of such compounds, which are rather insoluble in the case of unsubstituted salophen.

Let us now discuss the genesis of our $\mathrm{C}-\mathrm{C}$ coupled compounds. The best Schiff base which can be used for electronic reasons and its conformational characteristics is salophen (strictly planar), since the maximum of electronic delocalization is assured over the three conjugated aromatic rings. A rather obvious hypothesis is that, as in a normal pinacol reduction, ${ }^{14}$ which has in the present case the unusual characteristic of being reversible by the oxidative cleavage of the $\mathrm{C}-\mathrm{C}$ bond, the reduction of the imino group leads to a radical anion either dimerizing to $\mathrm{C}$ (pathway $a$ ) or adding to an unreacted imino group to form a free radical to the nitrogen (pathway $b$, intermediate D) which is further reduced to $\mathrm{C}$.

The key steps in both pathways $a$ and $b$ is the dimerization to produce $\mathrm{C}$ and $\mathrm{D}$. Both dimerizations should suffer from steric hindrance at the imino carbons. For this reason we carried out the same reduction on $\mathbf{2}$, where the imino hydrogens have been replaced by two methyl groups in the starting salophen ligand. The reduction of $\mathbf{2}$ carried out in THF with a rather

(14) (a) Allinger, N. Org. Synth. 1963, IV, 840. (b) Bloomfield, J. J.; Owsley, D. C.; Ainsworth, C.; Robertson, R. E. J. Org. Chem. 1975, 40, 393. (c) Schreibmann, A. A. P. Tetrahedron Lett. 1970, 4271. (d) Smith, J. G.; Ho, I. J. Org. Chem. 1972, 37, 653. (e) Jaunin, R.; Holl, R. Helv. Chim. Acta 1958, 41, 1783. (f) Jaunin, R.; Magnenat, J.-P. Helv. Chim. Acta 1959, 42, 328. (g) Bastian, J.-M.; Jaunin, R. Helv. Chim. Acta 1963, 46, 1248. (h) Shono, T.; Kise, N; Okazaki, E. Tetrahedron Lett. 1992, 33, 3347. 


\section{Scheme 6}
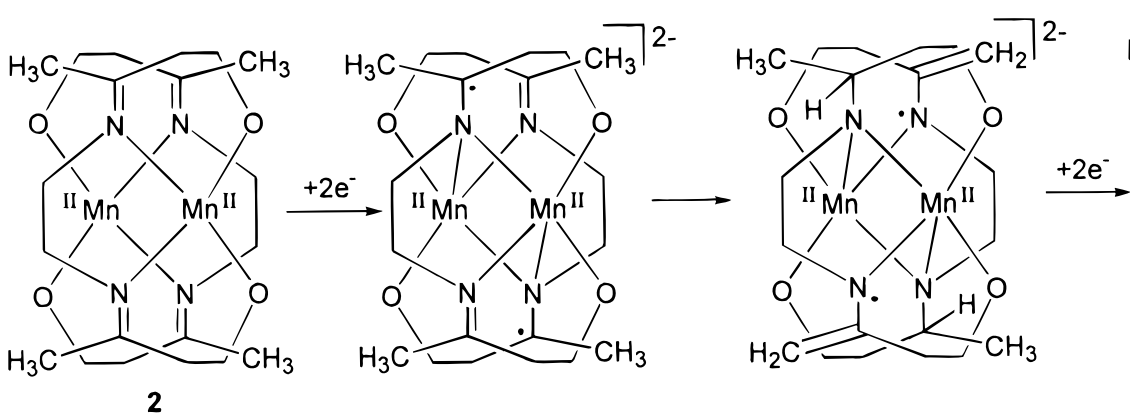
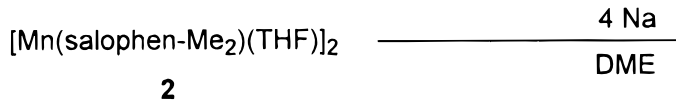

DME

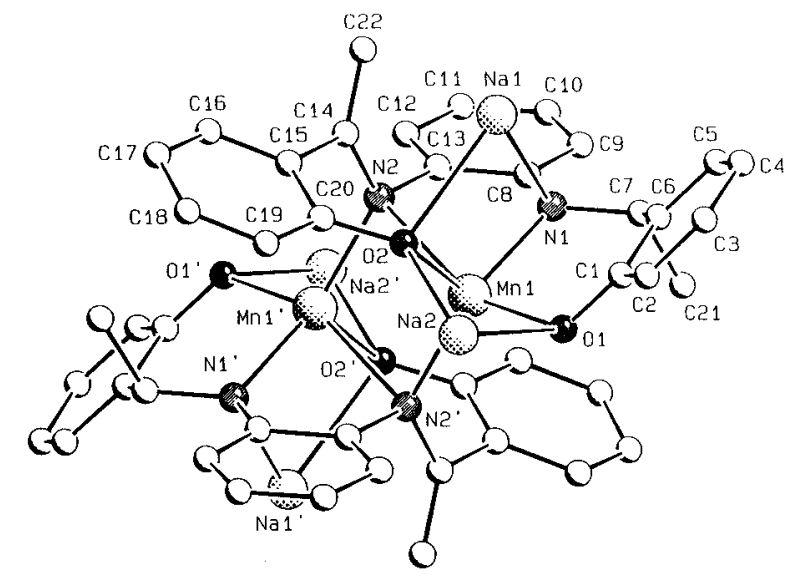

Figure 6. SCHAKAL view of complex 9. DME molecules bonded to sodium are omitted for clarity. Prime denotes a transformation of $-x$, $-y, 1-z$.

large excess of sodium metal gave $\mathbf{9}$ as a yellow crystalline solid upon recrystallization from DME. In this case, the preliminary generation of a radical anion is not followed by any dimerization, rather the radical at the carbon abstracts a hydrogen atom from a methyl group either of the same or of the other salophen of the dimer, to give a methylene and leading to the rearrangement shown in Scheme 6.

The bonding scheme displayed in Scheme 6 for 9 is based on the X-ray structure reported in Figure 6.

The centrosymmetric dimer contains two [Mn(salophen)] units, with the presence of a methyl substituent at C7 [C7$\mathrm{C} 21,1.515(7) \AA$ A ] and a methylene group at C14 [C14-C22, 1.354(8) $\AA$ ]. The latter one forms with the adjacent C14-N2 [1.392(6) A] a sort of azaallyl fragment, while C7-N1 is reduced to a single bond $[1.445(7) \AA]$. Dimerization occurs through the amido $\mathrm{N} 2$ which bridges asymmetrically the two $\mathrm{Mn}$ atoms, which are at a distance of 3.050(1) $\AA$ [Mn1-N2,

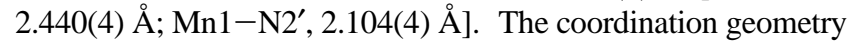
around the metal is a distorted trigonal bipyramid with $\mathrm{N} 1, \mathrm{O} 2$, and $\mathrm{N} 2$ in the axial positions. Na1 (bonded to $\mathrm{O} 1$ and $\mathrm{O} 2$ ) and $\mathrm{Na} 2$ (bonded to $\mathrm{O} 2$ and $\mathrm{N} 1$ ) are in a pseudotetrahedral environment (see Figure S9) completed by a DME molecule. The structural parameters not mentioned above do not deserve any particular comment (Table 4).

The temperature dependence of the magnetic moment of compounds 5-8 indicates antiferromagnetically coupled Mn(II) dimers. The best fitting values for $\mathbf{5}$ and $\mathbf{6}$ are $g=2.02, J$ $=-43.0 \mathrm{~cm}^{-1}, x=3.9 \%$ and $g=1.97, J=-40.8 \mathrm{~cm}^{-1}, x=$ $0.4 \%$, respectively. The exchange constant values found for
Table 4. Selected Bond Distances $(\AA)$ and Angles (deg) for Complex $9^{a}$

\begin{tabular}{|c|c|c|c|}
\hline $\mathrm{Mn} 1-\mathrm{O} 1$ & $2.116(4)$ & $\mathrm{Na} 2-\mathrm{O} 6$ & $2.355(5)$ \\
\hline $\mathrm{Mn} 1-\mathrm{O} 2$ & $2.119(3)$ & $\mathrm{O} 1-\mathrm{C} 1$ & $1.317(7)$ \\
\hline $\mathrm{Mn} 1-\mathrm{N} 1$ & $2.088(5)$ & $\mathrm{O} 2-\mathrm{C} 20$ & $1.338(6)$ \\
\hline $\mathrm{Mn} 1-\mathrm{N} 2$ & $2.440(4)$ & $\mathrm{N} 1-\mathrm{C} 7$ & $1.445(7)$ \\
\hline $\mathrm{Mn} 1-\mathrm{N} 2^{\prime}$ & $2.104(4)$ & $\mathrm{N} 1-\mathrm{C} 8$ & $1.381(7)$ \\
\hline $\mathrm{Na} 1-\mathrm{O} 2$ & $2.598(4)$ & $\mathrm{N} 2-\mathrm{C} 13$ & $1.451(8)$ \\
\hline $\mathrm{Na} 1-\mathrm{O} 3$ & $2.387(5)$ & $\mathrm{N} 2-\mathrm{C} 14$ & $1.392(6)$ \\
\hline $\mathrm{Na} 1-\mathrm{O} 4$ & $2.265(4)$ & C6-C7 & $1.530(8)$ \\
\hline $\mathrm{Na} 1-\mathrm{N} 1$ & $2.444(4)$ & $\mathrm{C} 7-\mathrm{C} 21$ & $1.515(7)$ \\
\hline $\mathrm{Na} 2-\mathrm{O} 1$ & $2.386(5)$ & $\mathrm{C} 14-\mathrm{C} 15$ & $1.480(9)$ \\
\hline $\mathrm{Na} 2-\mathrm{O} 2$ & $2.265(4)$ & $\mathrm{C} 14-\mathrm{C} 22$ & $1.354(8)$ \\
\hline $\mathrm{Na} 2-\mathrm{O} 5$ & $2.484(6)$ & & \\
\hline $\mathrm{N} 2-\mathrm{Mn} 1-\mathrm{N} 2^{\prime}$ & $96.0(1)$ & $\mathrm{Na} 2-\mathrm{O} 1-\mathrm{C} 1$ & $108.3(3)$ \\
\hline $\mathrm{N} 1-\mathrm{Mn} 1-\mathrm{N} 2^{\prime}$ & $138.2(2)$ & $\mathrm{Mn} 1-\mathrm{O} 1-\mathrm{C} 1$ & 121.7(3) \\
\hline N1-Mn1-N2 & 74.3(1) & $\mathrm{Na} 1-\mathrm{O} 2-\mathrm{Na} 2$ & $117.8(1)$ \\
\hline $\mathrm{O} 2-\mathrm{Mn} 1-\mathrm{N} 2^{\prime}$ & $108.7(1)$ & $\mathrm{Mn} 1-\mathrm{O} 2-\mathrm{Na} 2$ & 95.1(1) \\
\hline $\mathrm{O} 2-\mathrm{Mn} 1-\mathrm{N} 2$ & $82.7(1)$ & $\mathrm{Mn} 1-\mathrm{O} 2-\mathrm{Na} 1$ & $79.6(1)$ \\
\hline $\mathrm{O} 2-\mathrm{Mn} 1-\mathrm{N} 1$ & $110.2(1)$ & $\mathrm{Na} 2-\mathrm{O} 2-\mathrm{C} 20$ & $123.7(3)$ \\
\hline $\mathrm{O} 1-\mathrm{Mn} 1-\mathrm{N} 2^{\prime}$ & $108.7(1)$ & $\mathrm{Na} 1-\mathrm{O} 2-\mathrm{C} 20$ & $108.1(2)$ \\
\hline $\mathrm{O} 1-\mathrm{Mn} 1-\mathrm{N} 2$ & $154.7(1)$ & $\mathrm{Mn} 1-\mathrm{O} 2-\mathrm{C} 20$ & $124.8(3)$ \\
\hline $\mathrm{O} 1-\mathrm{Mn} 1-\mathrm{N} 1$ & 90.1(1) & $\mathrm{Mn} 1-\mathrm{N} 1-\mathrm{Na} 1$ & $83.9(2)$ \\
\hline $\mathrm{O} 1-\mathrm{Mn} 1-\mathrm{O} 2$ & 84.2(1) & Na1-N1-C8 & 109.4(3) \\
\hline O4-Na1-N1 & $153.6(2)$ & $\mathrm{Na} 1-\mathrm{N} 1-\mathrm{C} 7$ & 105.1(3) \\
\hline $\mathrm{O} 3-\mathrm{Na} 1-\mathrm{N} 1$ & $102.3(2)$ & $\mathrm{Mn} 1-\mathrm{N} 1-\mathrm{C} 8$ & $114.7(3)$ \\
\hline $\mathrm{O} 3-\mathrm{Na} 1-\mathrm{O} 4$ & $72.2(2)$ & $\mathrm{Mn} 1-\mathrm{N} 1-\mathrm{C} 7$ & $119.4(3)$ \\
\hline $\mathrm{O} 2-\mathrm{Na} 1-\mathrm{N} 1$ & $86.3(1)$ & C7-N1-C8 & $117.5(4)$ \\
\hline $\mathrm{O} 2-\mathrm{Na} 1-\mathrm{O} 4$ & $99.1(2)$ & $\mathrm{Mn} 1-\mathrm{N} 2-\mathrm{C} 14$ & $111.8(3)$ \\
\hline $\mathrm{O} 2-\mathrm{Na} 1-\mathrm{O} 3$ & 171.1(2) & $\mathrm{Mn} 1-\mathrm{N} 2-\mathrm{C} 13$ & $102.2(3)$ \\
\hline $\mathrm{O} 5-\mathrm{Na} 2-\mathrm{O} 6$ & 68.2(2) & $\mathrm{C} 13-\mathrm{N} 2-\mathrm{C} 14$ & $114.0(4)$ \\
\hline $\mathrm{O} 2-\mathrm{Na} 2-\mathrm{O} 6$ & $179.7(2)$ & $\mathrm{N} 1-\mathrm{C} 7-\mathrm{C} 6$ & $111.6(4)$ \\
\hline $\mathrm{O} 2-\mathrm{Na} 2-\mathrm{O} 5$ & $112.0(2)$ & $\mathrm{C} 6-\mathrm{C} 7-\mathrm{C} 21$ & $111.0(4)$ \\
\hline $\mathrm{O} 1-\mathrm{Na} 2-\mathrm{O} 6$ & $104.5(2)$ & $\mathrm{N} 1-\mathrm{C} 7-\mathrm{C} 21$ & $114.7(4)$ \\
\hline $\mathrm{O} 1-\mathrm{Na} 2-\mathrm{O} 5$ & $154.0(2)$ & $\mathrm{N} 2-\mathrm{C} 14-\mathrm{C} 22$ & $125.3(5)$ \\
\hline $\mathrm{O} 1-\mathrm{Na} 2-\mathrm{O} 2$ & 75.2(1) & $\mathrm{N} 2-\mathrm{C} 14-\mathrm{C} 15$ & $115.2(5)$ \\
\hline $\mathrm{Mn} 1-\mathrm{O} 1-\mathrm{Na} 2$ & $91.8(1)$ & $\mathrm{C} 15-\mathrm{C} 14-\mathrm{C} 22$ & $119.4(5)$ \\
\hline
\end{tabular}

${ }^{a}$ Prime denotes a transformation of $-x,-y, 1-z$.

5-8 show fairly strong antiferromagnetic coupling for these $\mu$-amido $\mathrm{Mn}$ (II) dimers. ${ }^{11}$ It is worth noting that these values are higher than those observed for $\mu$-hydroxo, $\mu$-alkoxo, $\mu$-phenoxo, and $\mu$-carboxylato $\mathrm{Mn}$ (II) $-\mathrm{Mn}$ (II) dimers (with exchange coupling constants of few $\mathrm{cm}^{-1}$ ) intensively studied ${ }^{1 \mathrm{c}, 15-17}$ within the investigation of inorganic model complexes of manganese-containing metalloproteins. ${ }^{1 \mathrm{c}}$

(15) Wieghardt, K.; Bossek, U.; Nuber, B.; Weiss, J.; Bonvoisin, J. Corbella, M.; Vitols S. E.; Girerd, J.-J. J. Am. Chem. Soc. 1988, 110, 7398.

(16) Menage, S.; Vitols, S. E.; Bergerat, P.; Codjovi, E.; Kahn, O.; Girerd, J.-J.; Guillot, M.; Solans X.; Calvet, T. Inorg. Chem. 1991, 30, 2666.

(17) Wieghart, K.; Bossek, K.; Bonvoisin, J.; Beauvillain, P.; Girerd, J.-J.; Nuber, B.; Weiss J.; Heinze, J. Angew. Chem., Int. Ed. Engl., 1986, 25,1030 . 


\section{Scheme 7}

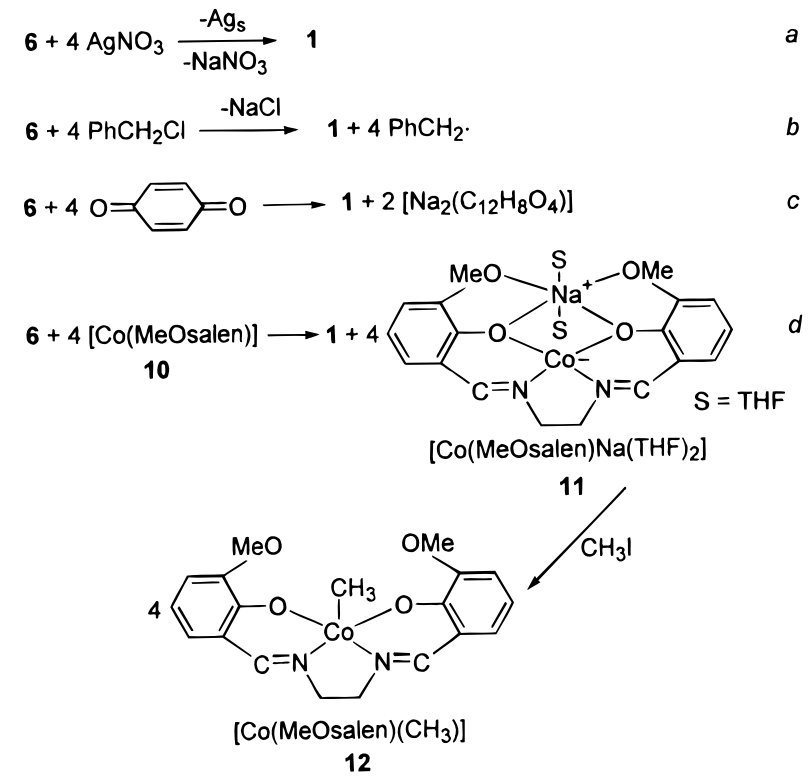

3. The $\mathbf{C}-\mathbf{C}$ Bonds Functioning as Two Electron Reservoirs. The most attractive property of complexes 5-8 is their tendency to function as reducing agents. In the first class we report reactions in which only the electrons stored in the $\mathrm{C}-\mathrm{C}$ bonds are used in combination with inorganic, organic, and organometallic substrates, ${ }^{18}$ as exemplified in Scheme 7.

The slow addition of $\mathrm{AgNO}_{3}$ or $\mathrm{PhCH}_{2} \mathrm{Cl}$ to 6 reveals the intermediacy of a violet solution, complex $\mathbf{5}$, before giving a solution containing exclusively 1 . Such reagents reverse the reduction pathway given in Scheme 2. In the case of benzyl chloride, the excess of reagent does not cause any oxidation of $\mathrm{Mn}(\mathrm{II})$, contrary to what has been reported for iron(II)-Schiff base derivatives. ${ }^{19}$ In reaction $b$ ) the benzyl radical has been partially identified as 1,2-diphenylethane. The reaction of 6 with $p$-benzoquinone can be easily followed by the appearance of the insoluble blue-green sodium salt of quinidrone. ${ }^{20}$ The reaction of $\mathbf{6}$ with the cobalt(II)-Schiff base $\mathbf{1 0}$ is very fast in THF and led to a deep green solution of the corresponding cobalt(I) derivative, ${ }^{4 \mathrm{~d}, 21}$ 11. The latter compound was easily identified via its conversion into the corresponding organometallic derivative, 12 (see the Experimental Section).22 The preliminary interaction with the reducible substrate is easily understandable in the case of reactions $a$ and $b$, while we should admit, in the case of reaction $d$ and $c$, the electron transfer pass through the interaction assured by the ability of $\mathbf{1 0}$ and

(18) Connelly, N. G.; Geiger, W. E. Chem. Rev. 1996, 96, 877 17.

(19) Floriani, C.; Fachinetti, G. J. Chem. Soc., Chem. Commun. 1973

(20) Depew, M. C.; Wan, J. K. S. in The Chemistry of Quininoid Compounds; Patai, I., Rappoport, Z., Eds; Wiley: New York, 1988; Vol. 21.

(21) Fachinetti, G.; Floriani, C.; Zanazzi, P. F.; Zanzari, A. R. Inorg. Chem. 1979, 18, 3469.

(22) (a) Sweany, R. L. In Comprehensive Organometallic Chemistry II; Abel, E. W., Stone, F. G. A., Wilkinson, G., Eds.; Pergamon: Oxford, U.K., 1995; Vol. 8; Chapter 1, p 42, and references therein. (b) Calligaris, M.; Randaccio, L. In Comprehensive Coordination Chemistry; Wilkinson, G., Gillard, R. D., McCleverty, J. A., Eds.; Pergamon: Oxford, U.K., 1987. (c) Pratt, J. M.; Craig, P. J. Adv. Organomet. Chem. 1973, 11, 404. (d) Calligaris, M.; Nardin, G.; Randaccio, L. Coord. Chem. Rev. 1972, 7, 385. (e) Bigotto, A.; Costa, G.; Mestroni, G.; Pellizzer, G.; Puxeddu, A.; Reisenhofer, E.; Stefani, L.; Tauzher, G. Inorg. Chim. Acta 1970, 4, 41. (f) Pattenden, G. Chem. Soc. Rev. 1988, 17, 361 and references therein. (g) Dodd, D.; Johnson, M. D. J. Organomet. Chem. 1973, 52, 1. (h) Pratt, J. M.; Craig, P. J. Adv. Organomet. Chem. 1973, 11, 414. (i) Randaccio, L.; Bresciani-Pahor, N.; Zangrando, E.; Marzilli, L. G. Chem. Soc. Rev. 1989, 18, 225. (j) Charlaud, J.-P.; Zangrando, E.; Bresciani-Pahor, N.; Randaccio, L.; Marzilli, L. G. Inorg. Chem. 1993, 32, 4256.
Scheme 8

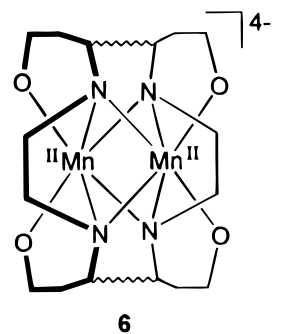

6

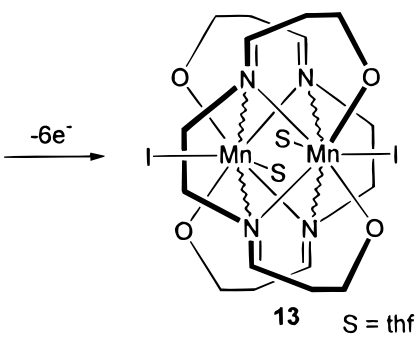

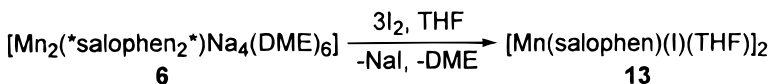

$p$-benzoquinone to bind alkali cations. The four reactions in Scheme 7 have some common characteristics.

(i) They use exclusively the $\mathrm{C}-\mathrm{C}$ bonds as a source of electrons with $[\mathrm{Mn}($ salophen $)]$ being restored in its original form, thus reversing the steps in Scheme 2. The simple cleavage of the $\mathrm{C}-\mathrm{C}$ and $\mathrm{Mn}-\mathrm{N}$ bonds as they are in $\mathbf{6}$ would lead to an overall migration of a salophen ligand from one $\mathrm{Mn}$ to the other one.

(ii) The reaction with a reducible substrate never occurs at the $\mathrm{C}-\mathrm{C}$ sites, thus supporting a long range electron transfer process, mediated by the metal sites in the structure.

A second class of reactions considers substrates which are able not only to use the electrons from the $\mathrm{C}-\mathrm{C}$ bonds but also from $\mathrm{Mn}$ increasing its oxidation state.

The reaction of $\mathbf{6}$ with a stoichiometric amount of iodine led to the corresponding $\mathrm{Mn}(\mathrm{III})$ derivative 13 (see Scheme 8), which was converted, in the presence of a large excess of iodine, to the triiodide derivative $14,\left[\mathrm{Mn}(\right.$ salophen $\left.)\left(\mathrm{I}_{3}\right)(\mathrm{THF})\right]$, whose structural parameters and figure are given in the Supporting Information. The same products 13 and 14 have been obtained by a direct oxidation of $\mathbf{1}$ with iodine.

The reaction of manganese(II) with dioxygen assisted by an intramolecular source of electrons, other than the metal, represents a novel approach in the vast area of manganese complexes reacting with $\mathrm{O}_{2} \cdot{ }^{1 \mathrm{~d}, 12 \mathrm{~b}, 15,23}$ This approach opens new perspectives in modeling studies concerning the Mn-assisted oxygen transfer reactions. ${ }^{24}$ In addition, to couple a metal with a source of electrons would engender a novel hypothesis on how to manage the redox chemistry of a transition metal in general. ${ }^{12 \mathrm{a}, 15,25}$

In this context we studied the reaction of dioxygen with 6 and $\mathbf{8}$, though the use of $\mathbf{8}$ was more favorable due to its considerable solubility in hydrocarbons. The results on the two compounds were quite the same. In the reaction with $\mathrm{O}_{2}\left[\mathrm{O}_{2}\right.$ : $\mathrm{Mn}=1: 1]$, complexes $\mathbf{6}$ and $\mathbf{8}$ behave as eight electron reducing agents, four of which come from the two $\mathrm{C}-\mathrm{C}$ bonds and four from the oxidation of $\mathrm{Mn}(\mathrm{II})$ to $\mathrm{Mn}(\mathrm{IV})$, with the concomitant reduction of dioxygen to oxide. Complex $\mathbf{1 6}$ was freed from $\mathrm{Na}_{2} \mathrm{O}$ by extracting the crude product with $n$-hexane, though

(23) (a) Coleman, W. M.; Taylor, L. T. Coord. Chem. Rev. 1980, 32, 1. (b) Horwitz, C. P.; Dailey, G. C.; Comments Inorg. Chem. 1993, 14, 283. (c) Bossek, U.; Weyehermüller, T.; Wieghardt, K.; Nuber, B.; Weiss, J. J. Am. Chem. Soc. 1990, 112, 6387.

(24) (a) Yamada, T.; Imagawa, K.; Nagata, T.; Mukaiyama, T. Chem. Lett. 1992, 2231. (b) Mukaiyama, T.; Yamada, T.; Nagata, T.; Imagawa, K. Chem. Lett. 1993, 327. (c) Nagata, T.; Imagawa, K.; Yamada, T.; Mukaiyama, T. Inorg. Chim. Acta 1994, 220, 283. (d) Nagata, T.; Imagawa, K.; Yamada, T.; Mukaiyama, T. Chem. Lett. 1994, 1259. (e) Imagawa, K.; Nagata, T.; Yamada, T.; Mukaiyama, T. Chem. Lett. 1995, 335. (f) MacDonnel, F. M.; Fackler, N. L. P.; Stern, C.; O'Halloran, T. V. J. Am. Chem. Soc. 1994, 116, 7431. (g) Nagata, T.; Imagawa, K.; Yamada, T.; Mukaiyama, T. Bull. Chem. Soc. Jpn. 1995, 68, 3241.

(25) (a) Brudvig, G. W.; Crabtree, R. H. Proc. Natl. Acad. Sci. U.S.A. 1986, 83, 4586. (b) Brudvig, G. W.; Crabtree, R. H. Progress in Inorganic Chemistry; 1989; Vol. 37. (c) Dismukes, G. C. Chem. Scr. 1988, 28 A, 99. 
Table 5. Comparison of Relevant Structural Parameters within the Mn(salophen) Units for Complexes 4-6, 9

\begin{tabular}{|c|c|c|c|c|c|c|c|}
\hline \multirow[b]{2}{*}{ dist of atoms from the $\mathrm{N}_{2} \mathrm{O}_{2}$ core, $\AA$} & \multirow[b]{2}{*}{$\mathrm{O} 1$} & \multicolumn{2}{|c|}{$4^{a}$} & \multicolumn{2}{|c|}{$\mathbf{5}^{b}$} & \multirow{2}{*}{$\frac{6}{0.021(3)}$} & \multirow{2}{*}{$\begin{array}{c}9 \\
0.233(3)\end{array}$} \\
\hline & & $0.038(13)$ & {$[0.050(13)]$} & $0.072(6)$ & {$[0.132(7)]$} & & \\
\hline & $\mathrm{O} 2$ & $-0.038(13)$ & {$[-0.054(13)]$} & $-0.334(7)$ & {$[-0.166(5)]$} & $-0.021(3)$ & $-0.218(3)$ \\
\hline & N1 & $-0.085(17)$ & {$[-0.107(16)]$} & $-0.771(1)$ & {$[-0.890(8)]$} & $-0.022(3)$ & $-0.469(4)$ \\
\hline & $\mathrm{N} 2$ & $0.125(20)$ & {$[0.116(17)]$} & $0.808(7)$ & {$[0.756(7)]$} & $0.022(3)$ & $0.452(4)$ \\
\hline & Mn1 & $-0.019(3)$ & {$[-0.021(3)]$} & $0.846(2)$ & {$[0.864(2)]$} & $-0.988(1)$ & $0.830(1)$ \\
\hline folding $^{c}$ along the $\mathrm{N} 1 \cdots \mathrm{O} 1$ line, deg & & $26.6(6)$ & {$[25.2(6)]$} & $18.5(3)$ & {$[20.6(3)]$} & $35.1(1)$ & $9.0(2)$ \\
\hline folding along the $\mathrm{N} 2 \cdots \mathrm{O} 2$ line, deg & & 7.2(7) & {$[1.0(5)]$} & $32.8(3)$ & {$[50.4(3)]$} & $38.0(1)$ & $15.7(2)$ \\
\hline $\begin{array}{l}\text { angle between } \mathrm{Mn} 1-\mathrm{N} 1-\mathrm{O} 1 \text { and } \\
\mathrm{Mn} 1-\mathrm{N} 2-\mathrm{O} 2 \text { planes, deg }\end{array}$ & & $6.2(6)$ & {$[6.8(5)]$} & $84.1(2)$ & {$[76.1(3)]$} & $74.8(1)$ & $73.3(1)$ \\
\hline angle between the mean $\mathrm{OC}_{3} \mathrm{~N}$ planes, deg & & $19.8(6)$ & {$[24.2(6)]$} & 74.4(3) & {$[75.4(3)]$} & $2.8(1)$ & $62.2(2)$ \\
\hline torsion angle $\mathrm{N} 1-\mathrm{C} 8-\mathrm{C} 13-\mathrm{N} 2$, deg & & 4(3) & {$[-5(3)]$} & $-6.0(13)$ & {$[-9.9(12)]$} & $0.4(5)$ & $-3.4(7)$ \\
\hline \multirow{2}{*}{ dist of atoms from the $\mathrm{Mn} 1-\mathrm{N} 1-\mathrm{N} 2$ plane, $\AA$} & $\mathrm{C} 8$ & $0.12(2)$ & {$[0.14(2)]$} & $0.484(11)$ & {$[0.449(10)]$} & $1.067(4)$ & $0.677(5)$ \\
\hline & $\mathrm{C} 13$ & $0.69(2)$ & {$[0.09(2)]$} & $0.530(10)$ & {$[0.575(9)]$} & $1.068(3)$ & $0.656(5)$ \\
\hline
\end{tabular}

${ }^{a}$ Values in square brackets refer to molecule B. ${ }^{b}$ Values in square brackets refer to Mn2, O3, O4, N3, N4, C28, C33. ${ }^{c}$ The folding is defined as the dihedral angle between the $\mathrm{Mn}, \mathrm{N}, \mathrm{O}$, and $\mathrm{OC}_{3} \mathrm{~N}$ planes of a six-membered chelation ring.

Table 6. Experimental Data for the X-ray Diffraction Studies on Crystalline Complexes 4-6, 9, and $\mathbf{1 4}^{a}$

\begin{tabular}{|c|c|c|c|c|c|}
\hline complex & 4 & 5 & 6 & 9 & 14 \\
\hline chemical formula & $\mathrm{C}_{50} \mathrm{H}_{38} \mathrm{Mn}_{2} \mathrm{~N}_{6} \mathrm{O}_{4}$ & $\mathrm{C}_{52} \mathrm{H}_{58} \mathrm{Mn}_{2} \mathrm{~N}_{4} \mathrm{Na}_{2} \mathrm{O}_{10}$ & $\mathrm{C}_{64} \mathrm{H}_{88} \mathrm{Mn}_{2} \mathrm{~N}_{4} \mathrm{Na}_{4} \mathrm{O}_{16}$ & $\mathrm{C}_{60} \mathrm{H}_{76} \mathrm{Mn}_{2} \mathrm{~N}_{4} \mathrm{Na}_{4} \mathrm{O}_{12}$ & $\mathrm{C}_{24} \mathrm{H}_{22} \mathrm{I}_{3} \mathrm{MnN}_{2} \mathrm{O}_{3} \mathrm{C}_{4} \mathrm{H}_{8} \mathrm{O}$ \\
\hline$a(\AA)$ & $24.632(4)$ & $14.241(3)$ & $12.678(3)$ & $13.303(3)$ & $9.886(8)$ \\
\hline$b(\AA)$ & $16.821(3)$ & $16.080(4)$ & $18.314(3)$ & $17.456(4)$ & $19.377(3)$ \\
\hline$c(\AA)$ & $10.098(3)$ & $12.426(2)$ & $14.807(2)$ & $14.039(3)$ & $15.883(4)$ \\
\hline$\alpha(\operatorname{deg})$ & 90 & 101.91(2) & 90 & 90 & 90 \\
\hline$\beta(\operatorname{deg})$ & 90 & $111.42(2)$ & $92.83(2)$ & $104.56(2)$ & $94.47(3)$ \\
\hline$\gamma(\operatorname{deg})$ & 90 & $88.71(2)$ & 90 & 90 & 90 \\
\hline$V(\AA)^{3}$ & $4184.0(16)$ & $2587.6(10)$ & $3433.8(11)$ & $3155.4(12)$ & $3033(3)$ \\
\hline$Z$ & 4 & 2 & 2 & 2 & 4 \\
\hline fw & 896.8 & 1054.9 & 1371.3 & 1247.1 & 894.2 \\
\hline space group & $P 2_{1} 2_{1} 2_{1}$ & $P \overline{1}$ & $P 2_{1} / n$ & $P 2_{1} / n$ & $P 2_{1} / n$ \\
\hline$T\left({ }^{\circ} \mathrm{C}\right)$ & 22 & 22 & 22 & 22 & 22 \\
\hline$\lambda(\AA)$ & 0.71069 & 1.54178 & 0.71069 & 0.71069 & 0.71069 \\
\hline$\rho_{\text {calcd }}\left(\mathrm{g} \mathrm{cm}^{-3}\right)$ & 1.424 & 1.354 & 1.326 & 1.313 & 1.958 \\
\hline$\mu\left(\mathrm{cm}^{-1}\right)$ & 6.31 & 46.41 & 4.40 & 4.68 & 34.74 \\
\hline transmission coeff & $0.885-1.000$ & $0.820-1.000$ & $0.828-1.000$ & $0.934-1.000$ & $0.691-1.000$ \\
\hline unique measured data & 7274 & 9751 & 6092 & 5531 & 5372 \\
\hline unique "observed" data & 3336 & 7403 & 5006 & 4423 & 4299 \\
\hline criterion for obsn & $F^{2}>-2 \sigma\left(F^{2}\right)$ & $F^{2}>0$ & $F^{2}>0$ & $F^{2}>0$ & $F^{2}>0$ \\
\hline $\begin{array}{c}\text { unique obs data } \\
{[I>\sigma 2(I)]}\end{array}$ & 1819 & 2728 & 2818 & 2016 & 2416 \\
\hline$R=$ & 0.046 & 0.074 & 0.045 & 0.044 & 0.045 \\
\hline$w \mathrm{R} 2=$ & 0.137 & 0.222 & 0.131 & 0.108 & 0.129 \\
\hline $\mathrm{GOF}=$ & 1.353 & 0.979 & 0.989 & 0.804 & 1.027 \\
\hline
\end{tabular}

${ }^{a} R=\sum|\Delta F| / \sum\left|F_{\mathrm{o}}\right|$ calculated on the unique observed data $[I>2 \sigma(I)] . \quad w \mathrm{R} 2=\left[\sum w\left|\Delta F^{2}\right|^{2} / \sum w\left|F_{\mathrm{O}^{2}}\right|^{2}\right]^{1 / 2}$ calculated on the unique "observed" data. $\mathrm{GOF}=\left[\sum w\left|\Delta F^{2}\right|^{2} /(\mathrm{NO}-\mathrm{NV})\right]^{1 / 2}$.

this was impossible for $\mathbf{1 5}$ due to its low solubility in hydrocarbons.

Complex 15 has been very recently reported as the unexpected result from the reaction of salophen $\mathrm{H}_{2}$ and $\mathrm{KMnO}_{4}{ }^{26}$ An analogous structure appeared on a substituted salen made from some $\mathrm{Mn}(\mathrm{III})$ oxidation. ${ }^{27}$ Complex $\mathbf{1 6}$ has been fully characterized, including the X-ray analysis, and shows a similar structure to $\mathbf{1 5}$, and it has been included in the Supporting Information. The reaction shown in Scheme 9 is peculiar in that the obtention of a di- $\mu$-oxo-manganese(IV) occurs directly from $\mathrm{Mn}$ (II) and dioxygen, and because the binucleating bonding mode of salophen requires a partial migration of the ligand across two Mn ions. The kind of synthesis reported for the two $\mu$-dioxo-Mn(IV) having the skeleton shown for $\mathbf{1 5}$ and $\mathbf{1 6}^{26,27}$ is serendipitous and so not particularly informative on their genesis.

As far as the first issue is concerned, we know that the reaction of either $\mathbf{1}$ or $\mathbf{4}$ with dioxygen results in the oxidation

(26) Torayama, H.; Nishide, T.; Asada, H.; Fujiwara, M.; Matsushita, T. Chem. Lett. 1996, 387-388.

(27) Bermejo, M. R.; Castiñeiras, A.; Garcia-Monteagudo, J. C.; Rey, M.; Sousa, A.; Watkinson, M.; McAuliffe, C. A.; Pritchard, R. G.; Beddoes, R. L. J. Chem. Soc., Dalton Trans. 1996, 2935-2944.
Scheme 9

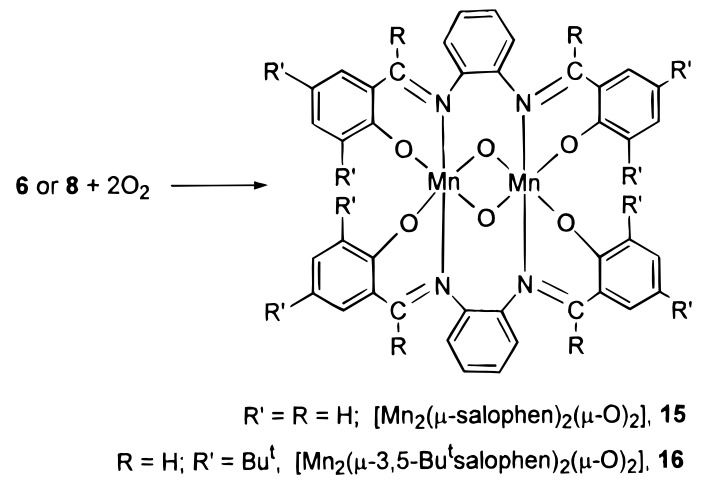

of the imino to an amido carbon, with the concomitant formation of a polymeric $\mu$-hydroxo-Mn(III). ${ }^{28}$ This proves that the reaction of $\mathbf{6}$ and $\mathbf{8}$ with dioxygen does not reverse the reduction pathway shown in Scheme 2 and that the reaction of $\mathrm{O}_{2}$ does not occur on 1. Therefore, unlike for the reactions reported in Scheme 7, the reaction of $\mathbf{6}$ and $\mathbf{8}$ with $\mathrm{O}_{2}$ does not restore the

(28) Gallo, E.; Solari, E.; Re, N.; Floriani, C.; Chiesi-Villa, A.; Rizzoli, C. Angew. Chem., Int. Ed. Engl. 1996, 35, 1981-1983. 


\section{Scheme 10}

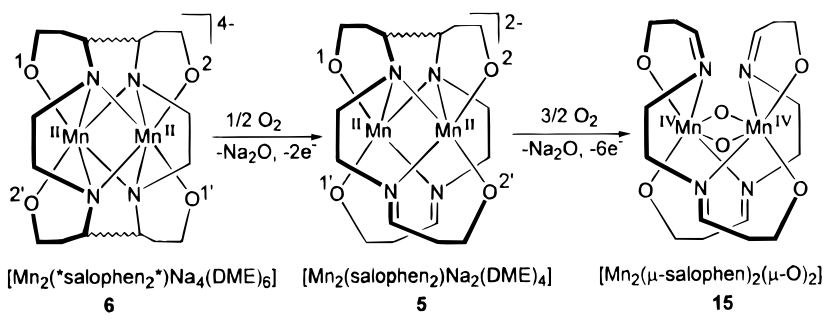

original [Mn(salophen)] fragment for further reactivity with $\mathrm{O}_{2}$. In addition, the reaction with $\mathrm{O}_{2}$ does not result in the cleavage of the intradimer $\mathrm{C}-\mathrm{C}$ and $\mathrm{Mn}-\mathrm{N}$ bonds in $\mathbf{6}-\mathbf{8}$, since the final compounds would have a salophen to $\mathrm{Mn}$ bonding mode different from that observed in $\mathbf{1 5}$ and 16. This bonding mode is compatible with the assumption that $\mathbf{5}$ and $\mathbf{7}$ are the precursors of 15 and 16 in the reaction with $\mathrm{O}_{2}$. Reacting 6 with a controlled amount of dioxygen gave $\mathbf{5}$ as violet crystals (see the Experimental Section). This proves that the intermediate compound reacting with $\mathrm{O}_{2}$ and leading directly to $\mathbf{1 5}$ is complex $\mathbf{5}$ and not 1. Further, the salophen ligand has in $\mathbf{5}$ and $\mathbf{7}$ the bridging bonding mode displayed in $\mathbf{1 5}$ and 16. The reaction pathway of $\mathbf{6}$, which will be the same for $\mathbf{8}$, is shown in Scheme 10. The sequence shows the two electron oxidation of $\mathbf{6}$ to $\mathbf{5}$, followed by the cleavage of two $\mathrm{Mn}-\mathrm{N}$ and one $\mathrm{C}-\mathrm{C}$ bonds in 5 with the incorporation of two bridging oxo ligands. Therefore the relative arrangement of the salophen ligand toward $\mathrm{Mn}$ in $\mathbf{1 5}$ remains as it is in $\mathbf{5}$, with salophen displaying a bridging bonding mode across two Mn ions.

The temperature dependence of the magnetic moment of $\mathbf{1 5}$ and its tert-butyl derivative $\mathbf{1 6}$ are quite similar and indicate antiferromagnetically coupled Mn(IV) dimers. The data were fitted using a Heisenberg Hamiltonian, with $S_{1}=S_{2}=3 / 2$, and including a correction for monomeric $\mathrm{Mn}(\mathrm{IV})$ impurities. ${ }^{11}$ The best fitting values for $\mathbf{1 6}$ are $g=1.86, J=-80.1 \mathrm{~cm}^{-1}$, and $x$ $=1.8 \%$. The antiferromagnetic coupling constant obtained for these bis $\mu$-oxo $\mathrm{Mn}(\mathrm{IV})$ dimers are similar to those observed for other bis $\mu$-oxo Mn(IV) Schiff base dimers (usually ca. 100 $\mathrm{cm}^{-1}$ ) with comparable $\mathrm{Mn}-\mathrm{Mn}$ distance. ${ }^{1 \mathrm{c}, 29}$

\section{Conclusions}

This report deals with a rather unique investigation on the chemical reduction of the very popular model Mn(II)-tetradentate Schiff base complexes. This approach led us to to discover (i) a novel mode of storing and releasing electrons based on the metal-assisted reversible formation (reductive coupling) and cleavage (oxidative decoupling) of $\mathrm{C}-\mathrm{C}$ bonds across two Schiff base ligands: (ii) the coupling of an electron reservoir centered at the ligand with the redox behavior of the metal. This kind of molecular battery has some original peculiarities: (a) the $\mathrm{C}-\mathrm{C}$ bonds function as a shuttle of two electrons without being involved in a reaction; (b) a large number of electrons can be stored and released by the system; (c) the metal assists longrange electron transfers from the $\mathrm{C}-\mathrm{C}$ bonds to the incoming substrates; and (d) the two redox systems, the metal and the ligand, can function independently from another or synergically.

\section{Experimental Section}

General Procedure. Unless otherwise noted, materials were obtained from commercial suppliers and used without further purification. Solvents were dried and distilled by standard methods prior to use. The syntheses of $\left[\mathrm{Mn}_{3} \mathrm{Mes}_{6}\right] \cdot$ toluene ${ }^{7}$ and 3,5-Bu${ }_{2}{ }_{2}$-salicylaldehyde

(29) Libby, E.; Webb, R. J.; Streib, W. E.; Folting, K.; Huffman, J. C.; Hendrickson, D. N.; Christou, J. Inorg. Chem. 1989, 28, 4037. have been carried out as reported. ${ }^{30}$ All compounds were handled using modified Schlenk techniques under a nitrogen atmosphere or in an inert atmosphere drybox under nitrogen. IR spectra were recorded on a Perkin-Elmer 1600 FT IR instrument.

Magnetic susceptibility measurements were made on a with a MPMS5 SQUID susceptometer (Quantum Design Inc.) operating at a magnetic field strength of $3 \mathrm{kG}$. Corrections were applied for diamagnetism calculated from Pascal constants. Effective magnetic moments were calculated by the equation $\mu_{\mathrm{eff}}=2.828\left(\chi_{\mathrm{Mn}} T\right)^{1 / 2}$, where $\chi_{\mathrm{Mn}}$ is the magnetic susceptibility per manganese atom. Fitting of the magnetic data to the theoretical equation were performed by minimizing the agreement factor, defined as

$$
R=\sum_{i} \frac{\left[\chi_{i}^{\mathrm{obsd}} T-\chi_{i}^{\mathrm{calcd}} T\right]^{2}}{\left(\chi_{i}^{\mathrm{obsd}} T\right)^{2}}
$$

through Levenberg-Marquardt routine. ${ }^{31}$

Synthesis of 1. [ $\left.\mathrm{Mn}_{3} \mathrm{Mes}_{6}\right] \cdot \mathrm{C}_{7} \mathrm{H}_{8}{ }^{7}(7.1 \mathrm{~g}, 7.31 \mathrm{mmol})$ was added to a THF $(500 \mathrm{~mL})$ solution of salophen $\mathrm{H}_{2}(6.90 \mathrm{~g}, 21.8 \mathrm{mmol})$ to give an orange solution which then turned deep red. The mixture was then refluxed for $12 \mathrm{~h}$ and concentrated to $1 / 3$ of its volume, and pentane $(150 \mathrm{~mL})$ was added. The resulting red crystalline solid was collected by filtration and dried in vacuo (7.10 g, 73\%), Crystals suitable for $\mathrm{X}$-ray analysis were obtained recrystallizing 1 from $\mathrm{CH}_{3} \mathrm{CN}$, to give the solvated form, $\left[\mathrm{Mn}(\text { salophen })\left(\mathrm{CH}_{3} \mathrm{CN}\right)\right]_{2}$. Anal. Calcd for $\mathbf{1}$, $\mathrm{C}_{48} \mathrm{H}_{44} \mathrm{Mn}_{2} \mathrm{~N}_{4} \mathrm{Na}_{4} \mathrm{O}_{6}$ : C, 65.31; H, 5.02; N, 6.35. Found: C, 65.13; $\mathrm{H}, 5.14 ; \mathrm{N}, 6.72$. IR (Nujol, $v_{\max } / \mathrm{cm}^{-1}$ ) 1609(s), 1581(s), 1528(m), 1296(m), 1178(s), 1145(s), 972(w), 914(m), 884(w), 852(w), 747(s), $529(\mathrm{~m})$. UV-vis (THF, $\left.8.10 \times 10^{-5} \mathrm{M}\right): \lambda=252 \mathrm{~nm}\left(\epsilon 71700 \mathrm{~cm}^{-1}\right.$ $\left.\mathrm{M}^{-1}\right), 298$ (43 700), 410 (46 500).

Synthesis of 2. $\left[\mathrm{Mn}_{3} \mathrm{Mes}_{6}\right] \cdot \mathrm{C}_{7} \mathrm{H}_{8}{ }^{7}(4.67 \mathrm{~g}, 4.81 \mathrm{mmol})$ was added to a THF $(300 \mathrm{~mL})$ solution of salophen $\left(\mathrm{CH}_{3}\right)_{2} \mathrm{H}_{2}(4.96 \mathrm{~g}, 14.4 \mathrm{mmol})$ to give an orange solution which then turned deep red. The mixture was then refluxed for $12 \mathrm{~h}$ and concentrated to $1 / 3$ of its volume, and pentane $(150 \mathrm{~mL})$ was added. The resulting orange crystalline solid was collected by filtration and dried in vacuo $(5.00 \mathrm{~g}, 74 \%)$. Anal. Calcd for 2, $\mathrm{C}_{52} \mathrm{H}_{52} \mathrm{Mn}_{2} \mathrm{~N}_{4} \mathrm{O}_{6}$ : C, 66.52; H, 5.58; N, 5.97. Found: C, 67.31; H, 5.30; N, 6.45. IR (Nujol, $v_{\max } / \mathrm{cm}^{-1}$ ) 1599(s), 1583(s), 1546(s), 1530(s), 1469(s), 1440(s), 1310(s), 1213(s), 1130(m), 861(m), 752(s), $738(\mathrm{~m}) . \mu=5.92 \mu_{\mathrm{B}}$ at $298 \mathrm{~K}$.

Synthesis of 3. $\mathrm{NaH}(1.56 \mathrm{~g}, 65.0 \mathrm{mmol})$ was added slowly ( $c a 3$ $\mathrm{min}$ ) without stirring, to an orange THF $(400 \mathrm{~mL})$ solution of salophen$\left(\mathrm{Bu}^{\mathrm{t}}\right)_{4} \mathrm{H}_{2}(16.0 \mathrm{~g}, 29.6 \mathrm{mmol})$. Gas evolution was immediately observed, with the concomitant formation of an orange suspension. The mixture was stirred at room temperature until gas evolution stopped ( $c a .10$ min) and then refluxed for $3 \mathrm{~h}$. The excess $\mathrm{NaH}$ was removed by filtration, and $\left[\mathrm{MnCl}_{2}(\mathrm{THF})_{1.5}\right]_{n}(6.92 \mathrm{~g}, 29.6 \mathrm{mmol})$ was added. The resulting red suspension was refluxed overnight and then evaporated to dryness, and the residue was extracted with toluene $(250 \mathrm{~mL})$ to eliminate $\mathrm{NaCl}$. The suspension was evaporated to dryness, $n$-hexane $(150 \mathrm{~mL})$ added, and the red crystalline solid was collected by filtration and dried in vacuo $(17.33 \mathrm{~g}, 88 \%)$. Anal. Calcd for $\mathbf{3}, \mathrm{C}_{80} \mathrm{H}_{108^{-}}$ $\mathrm{Mn}_{2} \mathrm{~N}_{4} \mathrm{O}_{6}: \mathrm{C}, 72.16 ; \mathrm{H}, 8.17 ; \mathrm{N}, 4.21$. Found: $\mathrm{C}, 72.22 ; \mathrm{H}, 8.66 ; \mathrm{N}$, 4.31, IR (Nujol), $v_{\max } / \mathrm{cm}^{-1}$ ) 1600(s), 1577(s), 1544(m), 1524(s), 1433(s), 1381(s), 1359(s), 1254(m), 1166(s), 832(m), 784(m), 746(s), 508(m).

Synthesis of 4. Complex $1(1.65 \mathrm{~g}, 1.87 \mathrm{mmol})$ was dissolved in pyridine $(50 \mathrm{~mL})$, the red solution was stirred at room temperature for $12 \mathrm{~h}$ and then evaporated to dryness, and pentane $(50 \mathrm{~mL})$ was added. The resulting red solid was collected by filtration and dried in vacuo $(1.50 \mathrm{~g}, 90 \%)$. Recrystallization from $\mathrm{Et}_{2} \mathrm{O}: \mathrm{Py}=80: 20$ gave crystals suitable for X-ray analysis. Anal. Calcd for $4, \mathrm{C}_{50} \mathrm{H}_{36} \mathrm{Mn}_{2} \mathrm{~N}_{6} \mathrm{O}_{4}$ : C, 66.97; H, 4.27; N, 9.37. Found: C, 66.83; H, 4.11; N, 9.20. IR (Nujol), $\left.v_{\max } / \mathrm{cm}^{-1}\right)$ 1606(s), 1580(s), 1540(s), 1525(s), 1482(m), 1387(s), 1349$(\mathrm{m}), 1327(\mathrm{~m}), 1301(\mathrm{~s}), 1252(\mathrm{w}), 1243(\mathrm{w}), 1216(\mathrm{w}), 1176(\mathrm{~s}), 1145(\mathrm{~s})$, 1124(m), 1037(m), 1028(m), 918(m), 841(m), 798(m), 771(m), 752(s), 740(s), 701(s), 600(m), 529(s), 460(m).

(30) Lorrow, J. F.; Jacobsen, E. N.; Gao, Y.; Hong, Y.; Nie, X.; Zepp, C. M. J. Org. Chem. 1994, 59, 1939.

(31) Press, W. H.; Flannery, B. P.; Teukolsky, S. A.; Vetterling, W. T. Numerical Recipes; Cambridge University Press: Cambridge, U.K., 1989. 
Synthesis of 5. Method A. Sodium sand $(0.30 \mathrm{~g}, 13.0 \mathrm{mmol})$ was added to a suspension of $1(0.82 \mathrm{~g}, 0.93 \mathrm{mmol})$ in DME $(300 \mathrm{~mL})$. The resulting red suspension was stirred at room temperature for $12 \mathrm{~h}$, the excess sodium then removed by extraction, the filtrate was concentrated to $1 / 3$ of its volume and a dilute mixture of $\mathrm{P}_{2} \mathrm{O}_{5}$-dried oxygen in nitrogen atmosphere allowed to enter. After 3 days red crystals suitable for $\mathrm{X}$-ray analysis was obtained and collected by filtration $(0.6 \mathrm{~g}, 56 \%)$. Anal. Calcd for $5, \mathrm{C}_{56} \mathrm{H}_{68} \mathrm{Mn}_{2} \mathrm{~N}_{4} \mathrm{Na}_{2} \mathrm{O}_{12}$ : C, 58.74; H, 5.99; N, 4.89. Found: C, 57.81; H, 5.32; N, 5.37. IR (Nujol, $\left.v_{\max } / \mathrm{cm}^{-1}\right) 1600(\mathrm{~s}), 1580(\mathrm{~s}), 1533(\mathrm{~m}), 1441(\mathrm{~s}), 1338(\mathrm{~s}), 1315(\mathrm{~m}), 1292-$ (s), 1264(s), 1167(s), 1148(m), 1109(m), 1086(s), 1031(m), 902(m), 752(s), 548(w), 477(w).

Method B. Complex $6(0.99 \mathrm{~g}, 0.72 \mathrm{mmol})$ was added as a solid to a DME $(150 \mathrm{~mL})$ suspension of $\mathbf{1}(0.64 \mathrm{~g}, 0.72 \mathrm{mmol})$, the resulting red solution was stirred at room temperature for $12 \mathrm{~h}$ and then concentrated to $1 / 3$ of its volume, and $n$-hexane $(100 \mathrm{~mL})$ was added. The resulting red crystalline solid was collected by filtration and dried in vacuo $(1.5 \mathrm{~g}, 90 \%)$. Recrystallization from DME gave crystals suitable for X-ray analysis. Anal. Calcd for $\mathbf{5}, \mathrm{C}_{56} \mathrm{H}_{68} \mathrm{Mn}_{2} \mathrm{~N}_{4} \mathrm{Na}_{2} \mathrm{O}_{12}$ : C, 58.74; H, 5.99; N, 4.89. Found: C, 58.62; H, 5.17; N, 5.22. UVvis (THF, $\left.6.73 \times 10^{-5} \mathrm{M}\right): \lambda=248 \mathrm{~nm}\left(\epsilon 70600 \mathrm{~cm}^{-1} \mathrm{M}^{-1}\right), 290$ (41 700), 394 (25 900).

Synthesis of 6. Sodium sand $(1.72 \mathrm{~g}, 74.78 \mathrm{mmol})$ was added to a suspension of $1(9.02 \mathrm{~g}, 10.23 \mathrm{mmol})$ in THF $(350 \mathrm{~mL})$. The resulting red suspension was stirred at room temperature for $12 \mathrm{~h}$, then the excess sodium was removed by filtration, and the filtrate evaporated to dryness. DME $(30 \mathrm{~mL})$ and $n$-hexane $(200 \mathrm{~mL})$ was added. The resulting yellow solid was collected by filtration and dried in vасио $(12.2 \mathrm{~g}, 87 \%)$. Recrystallization from DME gave crystals suitable for $\mathrm{X}$-ray analysis. Anal. Calcd for 6, $\mathrm{C}_{64} \mathrm{H}_{88} \mathrm{Mn}_{2} \mathrm{~N}_{4} \mathrm{Na}_{4} \mathrm{O}_{16}$ : C, 56.06; $\mathrm{H}, 6.47 ; \mathrm{N}, 4.09$. Found: C, 56.49; H, 6.06; N, 4.56. IR (Nujol, $\nu_{\max } / \mathrm{cm}^{-1}$ ) 1587(s), 1544(m), 1440(s), 1286(s), 1261(s), 1109(m), 1083(m), 1034(m), 1022(m), 754(m). UV-vis (THF, $\left.5.47 \times 10^{-5} \mathrm{M}\right): \lambda=244 \mathrm{~nm}(\epsilon 62500$ $\mathrm{cm}^{-1} \mathrm{M}^{-1}$ ), 298 (39 600), 378(sh) (12 000), 508 (3400).

Synthesis of 7. Complex $8(1.67 \mathrm{~g}, 1.02 \mathrm{mmol})$ was added as a solid to a DME (100 mL) suspension of $3(1.36 \mathrm{~g}, 1.02 \mathrm{mmol})$, the resulting red solution was stirred at room temperature for $12 \mathrm{~h}$ and then concentrated to $1 / 3$ of its volume, and the resulting red crystalline solid was collected by filtration and dried in vacuo $(2.5 \mathrm{~g}, 70 \%)$. Anal. Calcd for 7, $\mathrm{C}_{96} \mathrm{H}_{152} \mathrm{Mn}_{2} \mathrm{~N}_{4} \mathrm{Na}_{2} \mathrm{O}_{16}:$ C, 64.99; H, 8.64; N, 3.16. Found: C, 64.37; H, 8.70; N, 3.01.

Synthesis of 8. Sodium sand $(0.69 \mathrm{~g}, 30.0 \mathrm{mmol})$ was added to a suspension of $\mathbf{3}(7.47 \mathrm{~g}, 5.62 \mathrm{mmol})$ in DME $(100 \mathrm{~mL})$. The resulting red suspension was stirred at room temperature for $12 \mathrm{~h}$, and the excess sodium was removed by extraction. The mixture was then concentrated to $1 / 3$ of its volume, and heptane $(100 \mathrm{~mL})$ was added. The resulting yellow solid was collected by filtration and dried in vacuo $(6.0 \mathrm{~g}, 65 \%)$. Recrystallization from DME gave crystals suitable for X-ray analysis. Anal. Calcd for 8, $\mathrm{C}_{88} \mathrm{H}_{132} \mathrm{Mn}_{2} \mathrm{~N}_{4} \mathrm{Na}_{4} \mathrm{O}_{12}$ : C, 64.45; $\mathrm{H}, 8.11 ; \mathrm{N}, 3.42$. Found: C, 64.87; H, 8.42; N, 3.07. IR (Nujol, $v_{\max } / \mathrm{cm}^{-1}$ ) 1593(m), 1542(s), 1407(m), 1358(s), 1347(s), 1309(s), 1276(s), 1244(s), 1193(s), 1156(m), 1123(m), 1082(s), 1020(m), 862(s), 834(s), 736(m), 724(s).

Synthesis of 9. Sodium sand $(0.46 \mathrm{~g}, 20.0 \mathrm{mmol})$ was added to a suspension of $2(1.96 \mathrm{~g}, 2.09 \mathrm{mmol})$ in THF $(200 \mathrm{~mL})$. The resulting red suspension was stirred at room temperature for $12 \mathrm{~h}$, the excess sodium was removed by filtration, and the mixture was evaporated to dryness. DME $(30 \mathrm{~mL})$ and heptane $(100 \mathrm{~mL})$ were then added. The resulting yellow solid was collected by filtration and dried in vacuo $(2.0 \mathrm{~g}, 77 \%)$. Recrystallization from DME gave crystals suitable for X-ray analysis. Anal. Calcd for 9, $\mathrm{C}_{60} \mathrm{H}_{76} \mathrm{Mn}_{2} \mathrm{~N}_{4} \mathrm{Na}_{4} \mathrm{O}_{12}$ : C, 57.79; H, 6.14; N, 4.49. Found: C, 57.84; H, 6.45; N, 4.43. IR (Nujol, $v_{\max } /$ $\left.\mathrm{cm}^{-1}\right)$ 1581(s), 1537(m), 1431(s), 1290(s), 1241(s), 1191(m), 1107(m), 1081(s), 1033(m), 858(m), 748(s). $\mu=3.15 \mu_{\mathrm{B}}$ at $293 \mathrm{~K}$.

Reaction of Complex 6 with $\mathbf{A g N O}_{3}$. Complex 6 (1.04 g, 0.76 mmol) was added as a solid to a THF $(150 \mathrm{~mL})$ suspension of $\mathrm{AgNO}_{3}$ $(0.52 \mathrm{~g}, 3.04 \mathrm{mmol})$. The resulting red suspension was stirred at room temperature for $12 \mathrm{~h}$ and refluxed for $3 \mathrm{~h}$. The metallic silver and $\mathrm{NaNO}_{3}$ were removed by filtration, and the red solution concentrated to $1 / 3$ of its volume followed by the addition of $n$-hexane $(100 \mathrm{~mL})$. The resulting orange solid was collected by filtration and dried in vacuo $(0.40 \mathrm{~g}, 60 \%)$. Anal. Calcd for $1, \mathrm{C}_{48} \mathrm{H}_{44} \mathrm{Mn}_{2} \mathrm{~N}_{4} \mathrm{O}_{6}$ : C, 65.31; H, 5.02; N, 6.35. Found: C, 64.78; H, 4.53; N, 6.63.
Reaction of Complex 6 with $\mathbf{P h C H}_{2} \mathbf{C l}$. To a red benzene $(50 \mathrm{~mL})$ suspension of $\mathbf{6}(0.98 \mathrm{~g}, 0.71 \mathrm{mmol})$ was added, in a dropwise manner and at room temperature, a benzene $(50 \mathrm{~mL})$ solution of a fresh distilled $\mathrm{PhCH}_{2} \mathrm{Cl}(0.57 \mathrm{~mL}, 4.94 \mathrm{mmol})$. The resulting red suspension was stirred at room temperature for $12 \mathrm{~h}$ and refluxed for $4 \mathrm{~h}$. The $\mathrm{NaCl}$ was eliminated by filtration, the solution evaporated to dryness, and pentane $(100 \mathrm{~mL})$ was added. The resulting red solid was collected by filtration and dried in vacuo $(0.50 \mathrm{~g}, 78 \%)$. Anal. Calcd for [Mn(salophen)(benzene)], $\mathrm{C}_{26} \mathrm{H}_{20} \mathrm{MnN}_{2} \mathrm{O}_{2}: \mathrm{C}, 69.80 ; \mathrm{H}, 4.51 ; \mathrm{N}, 6.26$. Found: C, 69.34; H, 4.96; N, 5.49. IR (Nujol, $v_{\max } / \mathrm{cm}^{-1}$ ) 1608(s), 1533(s), 1314(m), 1272(w), 1179(m), 1150(m), 1030(w), 917(w), 853(w), 751(s), 699(m), 601(w), 542(w).

Reaction of Complex 6 with 1,4-Benzoquinone. To a THF (150 $\mathrm{mL})$ solution of $\mathbf{6}(3.33 \mathrm{~g}, 2.43 \mathrm{mmol})$ was added solid 1,4benzoquinone ( $1.36 \mathrm{~g}, 12.58 \mathrm{mmol})$. The resulting green suspension was stirred at room temperature for $1 \mathrm{~h}$ and then refluxed for $12 \mathrm{~h}$.

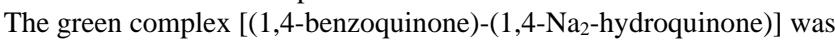
eliminated by extraction and identified by elemental analysis. The resulting red solution was evaporated to dryness, pentane $(100 \mathrm{~mL})$ added, and the resulting orange solid collected by filtration and dried in vacuo $(0.60 \mathrm{~g}, 78 \%)$. Anal. Calcd for $1, \mathrm{C}_{48} \mathrm{H}_{44} \mathrm{Mn}_{2} \mathrm{~N}_{4} \mathrm{O}_{6}$ : C, 65.31; H, 5.02; N, 6.35. Found: C, 65.50; H, 4.33; N, 6.25.

Synthesis of 12. The complex [Co\{salen $\left.\left.\left(\mathrm{OCH}_{3}\right)_{2}\right\}\right](0.66 \mathrm{~g}, 1.72$ mmol) was added as a solid to a THF $(150 \mathrm{~mL})$ suspension of $\mathbf{6}(1.18$ $\mathrm{g}, 0.86 \mathrm{mmol})$. The resulting green solution was stirred at room temperature for $12 \mathrm{~h}$, and a THF $(50 \mathrm{~mL})$ solution of $\mathrm{CH}_{3} \mathrm{I}(0.364 \mathrm{~g}$, $2.58 \mathrm{mmol}$ ) was added in a dropwise manner at $-60^{\circ} \mathrm{C}$. The resulting red solution was stirred at room temperature for $12 \mathrm{~h}$ and evaporated to dryness, then the red residue dissolved in $\mathrm{CH}_{2} \mathrm{Cl}_{2}(100 \mathrm{~mL})$ and then was poured into distilled water. The organic phase was collected, and the water was eliminated by azeotropic distillation. After 1 day at $-20{ }^{\circ} \mathrm{C}$, a red crystalline solid was collected by filtration and dried in vacuo $(0.5 \mathrm{~g}, 62 \%)$. ${ }^{1} \mathrm{H}$ NMR for $\left[\mathrm{Co}\left\{\operatorname{salen}\left(\mathrm{OCH}_{3}\right)_{2}\right\}\right]\left(\mathrm{CH}_{2} \mathrm{Cl}_{2}\right), \mathrm{C}_{20} \mathrm{H}_{23-}$ $\mathrm{Cl}_{2} \mathrm{CoN}_{2} \mathrm{O}_{4}$, (DMSO- $\left.d_{6}, 298 \mathrm{~K}\right): \delta 7.90(\mathrm{~s}, 2 \mathrm{H}) ; 6.76-6.65(\mathrm{~m}, 4 \mathrm{H})$; $6.30-6.27(\mathrm{~m}, 2 \mathrm{H}) ; 5.76(\mathrm{~s}, 2 \mathrm{H}) ; 3.74(\mathrm{~s}, 6 \mathrm{H}) ; 3.44-3.35(\mathrm{~m}, 4 \mathrm{H})$; $2.15(\mathrm{~s}, 3 \mathrm{H})$.

Synthesis of 13. To a stirred red THF $(50 \mathrm{~mL})$ solution of $6(0.95$ g, $0.70 \mathrm{mmol})$ was added, at $-60{ }^{\circ} \mathrm{C}$, a THF solution of $\mathrm{I}_{2}(58 \mathrm{~mL}$, $0.04 \mathrm{M}$ ). The resulting red suspension was stirred at room temperature for $12 \mathrm{~h}$ to give a red crystalline solid which was then collected by filtration and dried in vacuo $(0.67 \mathrm{~g}, 84 \%)$. Anal. Calcd for 13, $\mathrm{C}_{24} \mathrm{H}_{22} \mathrm{IMnN}_{2} \mathrm{O}_{3}$ : C, 50.72; H, 3.90; N, 4.93. Found: C, 50.05; H, 4.13; N, 4.73. IR (Nujol, $v_{\text {max }} / \mathrm{cm}^{-1}$ ) 1603(s), 1577(s), 1535(s), 1437(s), 1286(m), 1234(m), 1194(s), 1150(s), 1129(m), 872(m), 812(s), 761(s), 543(s). $\mu=4.72 \mu_{\mathrm{B}}$ at $293 \mathrm{~K}$.

Synthesis of 14. To a stirred red THF $(50 \mathrm{~mL})$ solution of $6(0.82$ g, $0.60 \mathrm{mmol})$ was added, at $-60^{\circ} \mathrm{C}$, a THF $(50 \mathrm{~mL})$ solution of $\mathrm{I}_{2}$ $(1.37 \mathrm{~g}, 5.40 \mathrm{mmol})$. The resulting red suspension was stirred at room temperature for $12 \mathrm{~h}$ and evaporated to dryness, and $\mathrm{Et}_{2} \mathrm{O}(100 \mathrm{~mL})$ was added. The red crystalline solid was collected by filtration and dried in vacuo $(0.8 \mathrm{~g}, 88.8 \%)$. Anal. Calcd for $14, \mathrm{C}_{24} \mathrm{H}_{22} \mathrm{I}_{3} \mathrm{MnN}_{2} \mathrm{O}_{3}$ : C, 35.06; H, 2.70; N, 3.41. Found: C, 35.73; H, 3.07; N, 3.35. IR (Nujol, $v_{\text {max }} / \mathrm{cm}^{-1}$ ) 1604(s), 1574(s), 1534(s), 1311(m), 1284(m), 1195$(\mathrm{m}), 1151(\mathrm{~m}), 1129(\mathrm{~m}), 1102(\mathrm{~m}), 812(\mathrm{~m}), 753(\mathrm{~m}), 544(\mathrm{~m}) . \mu=5.02$ $\mu_{\mathrm{B}}$ at $293 \mathrm{~K}$.

Synthesis of $\mathbf{1 5} \cdot 2 \mathrm{Na}_{2} \mathrm{O}$. Complex $\mathbf{6}(6.65 \mathrm{~g}, 4.85 \mathrm{mmol})$ was dissolved in pyridine $(150 \mathrm{~mL})$ to which was added anhydrous oxygen. The resulting brown solution was stirred at room temperature for $12 \mathrm{~h}$ and concentrated to $1 / 3$ of its volume, and $n$-hexane $(100 \mathrm{~mL})$ was added. The resulting brown solid was collected by filtration and dried in vacuo $(4.1 \mathrm{~g}, 87 \%)$. Anal. Calcd for $\mathbf{1 5} \cdot 2 \mathrm{Na}_{2} \mathrm{O}, \mathrm{C}_{44} \mathrm{H}_{36} \mathrm{Mn}_{2} \mathrm{~N}_{4} \mathrm{Na}_{4} \mathrm{O}_{9}$ : C, 54.67; H, 3.75; N, 5.80. Found: C, 54.03; H, 3.90; N, 5.48.

Synthesis of 16. Complex $8(1.1 \mathrm{~g}, 0.67 \mathrm{mmol})$ was dissolved in pyridine $(100 \mathrm{~mL})$ to which was added anhydrous oxygen. The resulting brown solution was stirred at room temperature for $12 \mathrm{~h}$ and then evaporated to dryness. Pentane $(50 \mathrm{~mL})$ was added to the residue, and the brown crystalline solid formed was collected by filtration and dried in vacuo $(0.6 \mathrm{~g}, 56 \%)$. Recrystallization from $n$-hexane gave crystals suitable for X-ray analysis. Anal. Calcd for $16, \mathrm{C}_{88} \mathrm{H}_{132} \mathrm{Mn}_{2}-$ $\mathrm{N}_{4} \mathrm{O}_{14}$ : C, 66.90; H, 8.42; N, 3.55. Found: C, 66.29; H, 7.18; N, 3.61.

X-ray Crystallography for Complexes 4-6, 9, and 14. Suitable crystals were mounted in glass capillaries and sealed under nitrogen. 
The reduced cells were obtained with use of TRACER. ${ }^{32}$ Crystal data and details associated with data collection are given in Tables 6 and S1 (Supporting Information). Data for all complexes were collected at room temperature $(295 \mathrm{~K})$ on a single-crystal diffractometer (Philips PW1100 for 4, Rigaku AFC6S for 5, 6 and $\mathbf{1 4}$ and Enraf-Nonius CAD4 for 9). For intensities and background, individual reflection profiles were analyzed..$^{33}$ The structure amplitudes were obtained after the usual Lorentz and polarization corrections, ${ }^{34}$ and the absolute scale was established by the Wilson method. ${ }^{35}$ The crystal quality was tested by $\psi$ scans showing that crystal absorption effects could not be neglected. Data were then corrected for absorption with $\mathrm{ABSORB}^{36}$ for 9 and using a semiempirical method ${ }^{37}$ for $4-6$, and 14. Anomalous scattering corrections were included in all structure factor calculations. ${ }^{38 b}$ Scattering factors for neutral atoms were taken from ref 38a for nonhydrogen atoms and from ref 39 for $\mathrm{H}$.

Structure solutions were based on the observed reflections $[I>$ $2 \sigma(I)]$. The refinements were carried out using the unique reflections with $F^{2}>0$ for 5, 6, 9, and $\mathbf{1 4}$ and with $F^{2}>-2 \sigma\left(F^{2}\right)$ for $\mathbf{4}$. The structures were solved by the heavy-atom method starting from a threedimensional Patterson map. ${ }^{40}$ During the least-squares the function minimized was $\sum w\left(\Delta F^{2}\right)^{2}{ }^{41}$ In the last stage of refinement the weighting scheme $w=1 /\left[\sigma^{2}\left(F_{\mathrm{o}}{ }^{2}\right)+(a P)^{2}\right]$ (with $P=\left(F_{\mathrm{o}}{ }^{2}+2 F_{\mathrm{c}}{ }^{2}\right) / 3$ was applied with $a$ resulting in the value of $0.0274,0.0959,0.0620$, 0.0369 , for $4-6,9$, and $\mathbf{1 4}$, respectively.

(32) Lawton, S. L.; Jacobson, R. A. "TRACER", a cell reduction program; Ames Laboratory: Iowa State University of Science and Technology, 1965.

(33) Lehmann, M. S.; Larsen, F. K. Acta Crystallogr. Sect. A: Cryst. Phys. Diffr. Theor. Gen. Crystallogr. 1974, A30, 580.

(34) Data reduction, structure solution, and refinement were carried out on a Quansan personal computer equipped with an INTEL Pentium processor and on an Encore 91 computer.

(35) Wilson, A. J. C. Nature (London) 1942, 150, 151

(36) Ugozzoli, F. Comput. Chem. 1987, 11, 109.

(37) North, A. C. T.; Phillips, D. C.; Mathews, F. S. Acta Crystallogr., Sect. A: Cryst. Phys., Diffr., Theor. Gen. Crystallogr. 1968, A24, 351359.

(38) International Tables for X-ray Crystallography; Kynoch Press: Birmingham, England, 1974; Vol. IV, (a) p 99, (b) p 149.

(39) Stewart, R. F.; Davidson, E. R.; Simpson, W. T. J. Chem. Phys. 1965, 42,3175 .

(40) Sheldrick, G. M. SHELX76, Program for crystal structure determination, University of Cambridge: Cambridge, England, 1976.
Refinement of all complexes was carried out first isotropically and then anisotropically for all the non-H atoms, except for the C44 methyl carbon atom in $\mathbf{5}$, which was found to be statistically distributed over two positions (A and B) isotropically refined with site occupation factors of 0.6 and 0.4 , respectively. The refinement of the THF molecule of crystallization in $\mathbf{1 4}$ was carried out by constraining the $\mathrm{C}-\mathrm{O}$ and $\mathrm{C}-\mathrm{C}$ distances to be 1.42(1) and 1.54(1) $\AA$, respectively.

The hydrogen atoms, except those associated to the disordered C44 methyl carbon in $\mathbf{5}$, which were ignored, partly located from difference maps, partly put in geometrically calculated positions, were introduced prior to the final refinements as fixed atom contributions with isotropic U's fixed at $0.08 \AA^{2}$ for $\mathbf{4}, 0.10 \AA^{2}$ for $\mathbf{5}, \mathbf{6}$, and $\mathbf{9}$, and $0.12 \AA^{2}$ for $\mathbf{1 4}$.

The final difference maps showed no peaks having chemical meaning above the general background.

Final atomic coordinates are listed in Tables $\mathrm{S} 2-\mathrm{S} 5$ for non-H atoms and in Tables S8-S11 for hydrogens. Thermal parameters are given in Tables S14-S17, and bond distances and angles are given in Tables $\mathrm{S} 20-\mathrm{S} 23{ }^{42}$

Acknowledgment. We would like to thank the "Fonds National Suisse de la Recherche Scientifique" (Bern, Switzerland, Grant No. 20-40268.94) and Ciba-Geigy (Basel, Switzerland) for financial support.

Supporting Information Available: Description of the structure for complex 14. X-ray crystallography for complex 16. Supplementary drawings for $4-6,9,14$, and 16. Tables giving crystal data and details of the structure determination, fractional atomic coordinates, bond lengths, bond angles, anisotropic thermal parameters, and hydrogen atom locations for 4-6, 9, 14, and 16. Magnetic properties of dimeric manganese complexes; plots of magnetic susceptibilities and $\mu_{\mathrm{B}}$ for $3, \mathbf{5}, \mathbf{6}, 16$ (50 pages). See any current masthead page for ordering and Internet access instructions.

\section{JA9640962}

(41) Sheldrick, G. M. SHELXL92, Program for crystal structure refinement; University of Göttingen, Göttingen, Germany, 1992.

(42) See the paragraph at the end of the paper regarding the Supporting Information. 